This is a self-archived version of an original article. This version may differ from the original in pagination and typographic details.

Author(s): Fingerroos, Outi

Title: Sähkö ja valon aika: näkökulma maaseudun moderniin muutokseen ennen 1960-lukua

Year: 2000

Version: Published version

Copyright: ㄷ 2000 Suomen Kielen Seura

Rights: In Copyright

Rights url: http://rightsstatements.org/page/lnC/1.0/?language=en

Please cite the original version:

Fingerroos, O. (2000). Sähkö ja valon aika: näkökulma maaseudun moderniin muutokseen ennen 1960-lukua. Sananjalka, 42, 181-208. https://doi.org/10.30673/sja.86622 
OUTI FINGERRoOs

\section{Sähkö ja valon aika - näkökulma maaseudun moderniin muutokseen ennen 1960-lukua}

\section{Tekniikan kulttuurisuus - vai kulttuurin teknisyys}

On hämmästyttävää, miten vähän sähköön liittyviä ilmiöitä on tutkittu Suomessa kansatieteen tai yleensä kulttuurin tutkimuksen kentässä (ks. silti Korhonen 1985a ja 1985b sekä Ruotsala 1992). Esimerkiksi Ruotsissa sähkön ja valon tutkimuksellinen arvo on jo laajemmin huomioitu. Jan Garnertin työ Anden i lampan: Etnologisk perspectiv på ljus och märker (1993) on erinomainen esimerkki kulttuurisen lähestymistavan valovoimasta. Georg Dragosin ja Gilda Stibyn kirjoittaman ja erään kylän paikallista kehitystä kuvaavan teoksen När elektriciteten kom: Om landbygdens elektrifiering med exempel från Edsbyn i Helsingland (1985) lukijakunnan taas voi olettaa ulottuvan jopa ammatillista ja tieteellistä yhteisöä laajemmalle. Kuitenkin Tampereella, Finlaysonin tehdassalissa maaliskuun 15. päivänä 1882 symbolisesti alkanut valon aikakausi rikkoi omalta osaltaan myyttiä perifeerisestä Suomesta. Tehdassalin valaisija Carl von Nottbeck toteutti unelmansa dynamojen ja lamppujen yhdistämisestä samaan aikaan, kun keksijä Thomas Alva Edison vasta esitteli ideaansa Pariisin maailmannäyttelyssä - areenalla, jossa myöhemmin luotiin toinen ja tunnetumpi suomalaiskansallisen itsetunnon peruskivistä. Edisonia tiedotettiinkin sähkeellä: "Valaistus asennettu 61. leveysasteelle. Täydellinen menestys." (Honkala 1966, 18; Kärnä 1993, 156.)

Sähköistyminen on kulttuurisesti haastava ilmiö, sillä tähänastisen suomalaisen sähkötutkimuksen perusteella tiedämme vain, mitä esimerkiksi Finlaysonin tehdassalissa tapahtui ensimmäisen hehkulampun sytyttyä. Ymmärrämme valon palamiseen tarvittavien fyysisten elementtien tarkoituksen. Tunnemme myös valtakunnan sähköistymiskehityksen päälinjat sekä siihen liittyneet keskustelut etenkin Etelä-Suomessa 1920- ja 1930-luvuilla toteutettujen sähköistyshankkeiden näkökulmasta (ks. Herranen 1996). Teknishistoriallinen 
analyysi sentään sijoittaa Suomen sähköistymisen osaksi agraarin yhteiskunnan muutosta ja Euroopassa tapahtunutta yleistä kehitystä (ks. Myllyntaus 1991). Lisäksi Oulujoen vesistön voimalaitosrakentamisen ja säännöstelyn aiheuttamia vaikutuksia on tarkasteltu toimien sosiokulttuuristen vaikutusten näkökulmasta (ks. Ruotsala 1992). Kulttuurista ja historiallisista ilmiöistä laajemmin kiinnostuneelle tutkijalle tämä ei kuitenkaan riitä. Historioitsija KarlErik Michelsen muotoileekin paradigman onnistuneesti:

Ruuvien, muttereiden, sylintereiden ym. yksityiskohtainen tuntemus ei [..] ole välttämätöntä teknologiatutkimuksessa. [..] Teknologiaa voidaan tarkastella myös ilmiönä, jota säätelevät samat voimat kuin muitakin yhteiskunnallisia asioita. Tämä ei kuitenkaan saa merkitä sitä, että teknologian materiaalinen perusta hylätään tyystin. Teknologian laaja määritelmä jo edellyttää, että tutkimuskohteina olevien koneiden synty, merkitys, rakenne ja ominaisuudet tunnetaan ainakin siinä määrin, kuin se on tarpeellista ilmiön ymmärtämisen kannalta. (Michelsen 1987, 191.)

Teknokraateilla ei siis ole aihetta determinismiin, sillä tekniikka on sisällöltään paljon muuta kuin kausaalisia syy-seuraus -suhteita. Ehkä tunnetuin laaja-alaisen katsantotavan puolestapuhuja sähköistymisen yhteydessä on yhdysvaltalainen historioitsija Thomas P. Hughes. Hän esittää teoksensa Networks of Power - Electrification of Western Society 1880-1930 (1983) johdantoluvussa ajatuksia, joita lainataan usein erilaisissa sähköalaan liittyvissä esityksissä. Hän näkee, että teknologiset kokonaisuudet koostuvat paitsi joukosta teknisiä aihelmia ja tieteellisiä lakeja myös taloudellisista resursseista, poliittisista voimista ja sosiaalisista suhteista. Hughesin mukaan historioitsijan pitääkin pyrkiä laaja-alaiseen katsantokantaan, jotta hän löytäisi teknisten ilmiöiden taustalla piilevän syiden verkoston. Sähköiset järjestelmät ilmentävät yhteiskunnan fyysisiä, henkisiä ja symbolisia voimavaroja. Ne kertovat kontekstista ja vaikuttavat kontekstiin sekä ovat sosiaalisten muutosten syitä ja seurauksia. Tekniikka onkin ajan kategoria: moniulotteinen suhteiden ja muutosten järjestelmä, joka sijoittuu aikaan sekä vertikaalisesti että horisontaalisesti. (Hughes 1983, 1-6/passim.)

Historioitsija Ruth Schwartz Cowan on vastaavanlaisen kokonaisvaltaisen katsantokannan kannattaja kotitaloushistorian alalla. Vertaankin häntä Thomas Hughesiin, sillä siinä, missä Hughes peräänkuuluttaa tekniikan taustalla vaikuttavien syiden selvittämistä, Cowan pitää koteja yhtä todellisina teknologisina systeemeinä, työprosessien ilmentäjinä sekä industrialisaation kohteina kuin tehtaita ja hiilikaivoksia. Siten kuva kodin eristäytyneisyydestä on väärä, sillä naiset tekevät siellä palkatonta kotitaloustyötä, joka on suoraan riippuvaista eiihmislähtöisistä energiaresursseista ja ulkopuolisista markkinoista. Ruuanlaiton, vaatetuksen, terveydenhuollon, kuljetuksen, veden, kaasun, maaöljyn ja sähkön valjastaminen markkinavoimille onkin merkinnyt siirtymää tuotosta kulutukseen sekä sen markkinointiin. (Cowan 1983, 4-13, 44-45, 69-71, 92-100.) 


\section{Valtakunnan sähköistysraivo ja paikalliset innovaattorit}

Valtakunnan sähköistymisen kannalta oleellisinta lienee innovaation hyväksi tehty pioneerityö, sillä pelkkä halu ei ole koskaan yksin riittänyt. Tarvittiin puolestapuhujia, rahoituksesta kiinnostuneita liikemiehiä ja tietotaidon omaavia teknikkoja. Etenkin Timo Myllyntaus korostaa heidän merkitystään, sillä 1900luvun Suomessa vain harvat sähköteknikot hallitsivat kaikki kolme yhteistyösektorin ulottuvuutta. (Myllyntaus 1991, 24.) Tässä suhteessa tamperelainen tekniikan harrastaja sekä liike- ja lehtimies Fritz Wilen oli poikkeuksellinen lahjakkuus. Sanomalehtimies toteutti lehtien sivuilla käydyn mielikuvakirjoittelun katujen sähköistämisestä ja ryhtyi liikemieheksi hankkien amerikkalaisen sähköalan toiminimen Thomson-Houston International Electric Light Co:n Suomen edustuksen. Tampereen kadut valaistiinkin marraskuun 15. päivänä 1888 maamme ensimmäisen kunnallisen sähkölaitoksen tuottamalla energialla. (Hietala 1987, 226, 243; Jaakkola 1982, 17-19; Simola 1993, 318.) Vastaaviin monitaitajiin Suomen sähköistymisen historiassa lukeutuvat Hannoverissa tekniikkaa opiskelleet Carl Wahl ja Axel Gottfrid Strömberg. Ensimmäinen aloitti dynamojen valmistamisen Paul Wahlin konepajalla Varkaudessa ja toimi myöhemmin Paul Wahl \& Co Elektriska Afdelningenin johtajana. Jälkimmäinen perusti oman sähköä, koneita ja sähkölaitoksia toimittavan yrityksen. (Eriksson 1993, 60-62.)

Pioneerityön kannalta historioitsija Marjatta Hietala on tehnyt oleellisen huomion. Hän korostaa, että maantieteellinen periferia on syytä erottaa tiedollisesta periferiasta, sillä jos tutkimuksen kohteena ovat innovaatiot ja osaaminen, ne eivät noudata apriorisesti maantieteellistä hierarkiaa. Hän haluaa samalla kumota myytin perifeerisestä Suomesta, sillä esimerkiksi suomalainen tiedontuotantojärjestelmä oli eurooppalaista huippuluokkaa taulustolaitoksen perustamisesta (1749) asti. Sen kuvattiin merkitsevän suomalaiselle yhteiskuntajärjestelmälle samaa kuin höyry ja sähkö rautateiden ja lennättimen välityksellä. Suomalaisten tiedonhankinta perustuikin monipuolisuuteen, sillä malleja etsittiin erilaisista lähteistä. Monet sähköalan uutuudet haettiin pioneerien toimesta ulkomailta ja sovellettiin täällä uudella tavalla käytäntöön. Kaiken takana oli suuri aate, jonka yhdet pukivat nationalismin viittaan, toiset taas sivistysuskon ja henkisen pääoman kasvattamisen kuoreen. Kolmannet vetosivat uskontoon, työväen- taikka raittiusaatteeseen. Yhteisenä päämääränä oli nostattaa Suomi sivistys- ja kulttuurimaiden rinnalle. (Hietala 1991, 8-11.) Sähkön kulttuuriseen olemukseen kuului siis selkeä mielikuvallisuus, jopa orastavan itsenäisyyden siemen. Se toimi luovan mielen viestinä ja symbolina muille.

Mielikuvallisuus puettiin käytännön tasolla monenlaisiin mainoslauseisiin. Sähköpropaganda ja sen ohessa toteutettu valistustyö täyttääkin ylhäältäpäin toteutetun (ideologisen) muutospyrkimyksen tuntomerkit. Pellervo-Seura aloitti 
jo vuonna 1916 sähkökonsulentin avulla tehtävän valistus- ja neuvontatoiminnan. Idean isänä oli Maarian "sähköpastori" J. R. Ellilä. Pari vuotta myöhemmin Hankkijan sähköosastoon liitetty Pellervo-Seuran sähkötekninen neuvontaosasto sai toteutettavakseen jo noin 500 sähkölaitoshanketta. (Honkala 1966, 32.) Järkevä suunnittelu ja harkinta tosin unohtuivat kovassa kiireessä liian usein, kuten A. A. Sarparanta kirjoittaa:

Kuumeisella kiireellä perustettiin pienempiä ja suurempia sähköyhtymiä. Useinkin ilman harkintaa ryhdyttiin rakentamaan mitä erilaisempia sähkölaitoksia. Missä sattui olemaan voimakone, sinne hankittiin generaattori, millainen tahansa satuttiin saamaan, kysymättä sen laatua, kokoa, jännitettä y.m. tärkeitä seikkoja. Johtimen saanti oli vaikeinta ja sen tähden valon saannin toivossa käytettiin mitä vain, kunhan se vain oli metallia. Ja niinhän saatiin sähkövaloa, jonka valaiseminen oli vähän niin ja näin muualla paitsi ehkä konehuoneessa ja sen lähimmässä ympäristössä. (Sarparanta 1938, 366.)

Marttajärjestö toimi valistusaatteen ylläpitäjänä omalla sarallaan. Se määritteli kodin ihanteen, johon kuului oleellisena osana nainen ja teollistumisen mukanaan tuoma porvarillinen ydinperhe. Ydinperheeseen kulminoituivat isänmaallisuus, sivistyneistön luoma velvollisuusetiikka ja uuden keskiluokan sivistyspyrkimykset. Puhdas koti pyhitettiin tunnesiteisiin perustuvan perheelämän tyyssijaksi, jossa naisella oli taloudellisen, kasvatuksellisen ja kodinhoidollisen "hengettären" rooli. (Ollila 1993, 47-50, 56.) Seuraava Emäntälehden kirjoitus, joka on peräisin vuodelta 1922, kuvaa selkeästi yläluokkaisen valistuspyrkimyksen henkeä. Hyötyajattelu, sähköntarve ja itsenäistyneen valtion romanttis-liberalistinen tahdonvoima on valjastettu propagandatarkoituksessa uuden ihanteen luomiseen.

- Mikä on kotitalousopetuksen tehtävä?

- Määritelmä: Kotitalousopetus on tointa, jolla osoitetaan miten vähimmällä vaivalla ja kustannuksilla saa eniten aikaan kotitaloudessa.

- Mihin suuntaan on siis kotitalousopetus suunnattava?

- Taloudellisen järjen ja järjestelykyvyn kehittämiseen.

- Millaisia opettajia siis tarvitaan?

- Tarvitaan fysiologeja, kemistejä, insinöörejä ja arkkitehteja.

- Mikä on seurauksena tällaisesta opettajakunnasta?

- Työvoiman vapautuminen ja henkisen tason nouseminen.

Keittiö, missä emäntä kaasun ja sähkön, vesijohdon ja likaviemärin, koneitten ja ravintolaskelmien avulla ohjaa taloutta, on oleva se ihanne, johon jokaisen talousopettajan on opetettava kasvattiaan pyrkimään taloudellisessa elämässään. Päämäärän täytyy olla selvillä ennen kuin ryhtyy opettamaan. (Emäntälehti 1922, 34-35.)

Erityisen sysäyksen maaseudun sähköistämisliike sai sota-ajan maaseudulla vallinneista olosuhteista. Raha, elpynyt teollisuus, kilpailu työvoimasta ja maaseudulla vallinneet kurjat valaistusolot saivat maalaisväestön laajoilla 
alueilla "sähköiseksi". (Sarparanta 1938, 366.) Suomalaisille naisille osoitetussa kirjoituksessa onkin samankaltaisuuksia niiden 1920-luvun keskustelujen kanssa, joita julkaistiin mm. Teknillisessä aikakauslehdessä. Kirjoitusten taustalla on sekä tiedostettu että tiedostamaton pyrkimys pienyhteisön ja lopulta koko elämäntavan muuttamiseen. Kyseessä on laaja makrotason integraatiokehitys, Günter Wiegelmannin (1977) "Exogene Dominante" tekijöineen ${ }^{1}$.

Ruotsalainen museointendentti Anders Björklund pitää perinteisen kollektivismin murtanutta ja teollistumiseen ja kaupungistumiseen johtanutta kehitystä kaikkein vallankumouksellisimpana muutoksena. Se loi uusia normeja ja ideaaleja, sillä avainsana "tehokkuus" valjastettiin jopa markkinavoimien sloganeihin. (Björklund 1986, 10-11, 13, 16.) Perustavanlaatuisen strukturaalisen muutoksen perusluonne paljastuu myös Stephen Kernin kirjoittamassa teoksessa The Culture of Time and Space 1880-1918 (1983). Siinä Kern tulkitsee 1900-luvun alun muutoksen ilmentävän siirtymää historiallisesta ajasta joukkoon privaatteja aikoja. Kern nostaa sähkön ja elokuvat muutoksen

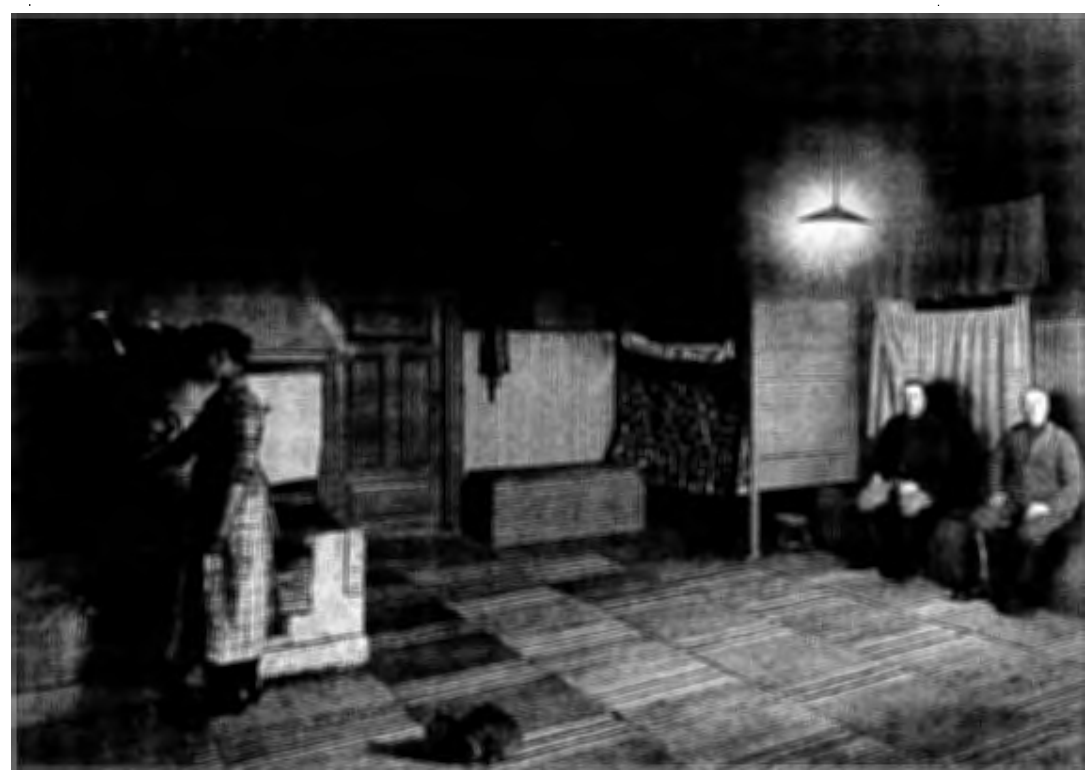

Lounais-Suomen Sähkö-Osakeyhtiön tuottamalla sähköllä valaistu tupa Paimion Rajalahdessa vuonna 1930. Kuva: Paimion Sähkömuseo.

1 "Exogene Dominanten" piiriin kuuluvat tekijöinä mm. kirkko, valtio, tekniikka, luonnonolosuhteet, taloudellinen tilanne ja rakenne, sosiaalinen struktuuri, asumisolot, kommunikaatiostruktuuri ja yleinen pääomasuuntautuneisuus. (Wiegelmann 1977, 41). 
keskeisiksi indikaattoreiksi, sillä ne muuttivat suoraviivaisen ajankeston toiseksi ja rikkoivat päivän ja yön välisen raja-aidan. (Kern 1993, 15, 28, 33-35, 64.) Tällainen syvärakenteen muutos loikin pohjan kaikelle 1900-luvun mikro- ja makrotason liikehdinnälle. Käytännössä vallankumouksellinen strukturaalinen muutos toteutui mm. vanhan perhe- ja sukukeskeisen yhteisömallin hajotessa. Tilalle tuli teollisuusyhteiskunnan privaatti ydinperhemalli, jonka symbolisena perustana toimi aluksi tehokas äiti.

\section{Sähköistymisen kääntöpuoli-murroksia myös mikrotasolta}

Edellä esitetty kuvaa varsin positiivisessa sävyssä tilannetta vuoden 1918 sisällissodasta toipuvassa Suomessa. Sotien jälkeinen lähtökohta oli ennemmin kaksijakoinen - kuten muinaisitalialainen alun ja lopun jumala Janus. Suomen sähkölaitoshistoriikin kirjoittaja Niilo Honkala kuvaakin maalaisväestön tuloa "sähköiseksi" kaikinpuolisen pimeyden näkökulmasta:

Tultiin sitten vuoteen 1918, tuohon historiallisesti, poliittisesti ja kansallisesti pimeään vuoteen. Se oli pimeää aikaa myös valaistusolojen kannalta. Ulkomaisen paloöljyn saanti loppui. Jouduttiin käyttämään jos jonkinlaista valaistusneuvoa karbiidilampusta kynttilään jopa päreeseen asti. Tästä pimeydestä oli yritettävä löytää jotain ratkaisua kustannuksista ja kannattavuudesta piittaamatta. Muuta mahdollisuutta kuin sähkö ei juuri ollut käytettävissä. (Honkala 1966, 32.)

Tällainen kaksijakoinen kuva on perusteltu yleisesti ja etenkin historiallisesta näkökulmasta, sillä sodan seurauksena käytiin aallonpohjassa, josta oli vain yksi suunta eteen: ylöspäin. Talous- ja sosiaalihistorioitsija Pertti Haapala niputtaa kriisin lopputuloksen yhteiskunnan muuttumisen nimiin: Suomesta tuli nationalismin ja sosialismin värittämästä "kansalaisuskonnollisuudestaan" huolimatta moderni ja liberaali yhteiskunta - mutta vasta vuonna 1919. Tällöin perustettiin hallitusmuodoltaan tasavaltainen kansalaisyhteiskunta, jossa oli yhdenvertaiset kansalaisvapaudet ja poliittiset oikeudet takaava länsieurooppalainen hallitusmuoto, valtiollinen järjestyskoneisto, virkamiehistö, kunnallishallinto, finanssihallinto, maanomistusoikeus ja verotusjärjestelmä. (Haapala 1995, 250-254.) Tämä kuvaakin maailmansodan aiheuttaman muutoksen januskasvoista dualismia: sen luonnetta vanhan loppuna ja uuden alkuna. ${ }^{2}$ Suomen energiatekniikan ja valaistuksen kannalta uusi vaihe merkitsi ensimmäisen todellisen sähköistysaallon alkua. Tästä nouseekin 1920-lukua kuvaava nimitys "sähköistysraivon" aika.

\footnotetext{
${ }^{2}$ Huomaa, että tämä ei tapahtunut hetkessä vaan historiallisen kehityksen tuloksena. "Länsimainen" Suomi oli olemassa koko ajan. Esim. Ruotsin lait (1734) jäivät voimaan Suomen suuriruhtinaskunnassa ja sittemmin maa sai oman "länsimaisen" lainsäädäntöelimensä, säätyvaltiopäivät ja lopuksi yksikamarisen eduskunnan.
} 
Jottei kuva sähköistymisestä jäisi edelleen torsoksi, muistutan, että sähköistymisen - niin kuin minkä tahansa muunkin muutoksen - taustalla olivat mm. 1860-luvun nälkävuodet ja pula, mitkä aiheuttivat henkisen ja taloudellisen esteen kehitykselle. Elpyminen alkoi 1870-luvulla, ja erilaisten innovaatioiden leviämiselle tarvittavat taloudelliset, sosiaaliset ja sivistykselliset edellytykset saavutettiin suuressa osassa maata vasta 1890 -luvulla. Varsinkin maaseudun sähköistymishistorian kannalta tämä oli oleellista, sillä 1800-luvun viimeisinä vuosikymmeninä Suomen maaseudulle syntynyt aatteellinen ilmapiiri sisälsi luovaa kehitystä ja tietoisen talonpoikaisen pyrkimyksen uudistuksiin. (Soininen 1982, 27-28; Virrankoski 1986, 544.) Se oli edellytys ja voimavara, joka mahdollisti tekniikan kehityksen hyväksikäytön. Historioitsija Pentti Virrankoski nimittää tällaista työväenliikkeeseen verrattavaa kokonaisuutta Suomen talonpoikaisliikkeeksi. Sen voi tulkita olleen eräänlainen suomalaisen talonpojan muutoksen ääni:

Tässä tarkoitetut aatteet voidaan ainakin teoriassa hahmotella kokonaisuudeksi, jonka nimitykseksi sopisi Suomen talonpoikaisliike. Mallina on tietysti ollut tuttu termi työväenliike. Tämä lienee oikeutettua, koska talonpoikaisliike voidaan perusteiden ja pyrkimysten suurista eroista huolimatta rinnastaa eräissä suhteissa työväenliikkeeseen. Molempien päämääränä oli laajan sosiaalisesti ja ammatillisesti erottuvan ihmisryhmän kaikinpuolinen kohottaminen. (Virrankoski 1986, 544.)

Onkin helppo yhtyä Virrankosken periaatteelliseen näkemykseen, jonka mukaan suomalaisen talonpoikaiskulttuurin hajoaminen ja sulautuminen osaksi yleiskulttuuria on yksipuolinen ja toisen maailmansodan jälkeiseen aikaan sidottu näkemys. "Maahenkeen" sisältyi luovaa kehitystä ja sisäsyntyistä pyrkimystä tietoiseen toimintaan, mikä ilmeni esimerkiksi Santeri Alkion, maalaisliiton ja osuustoimintaliikkeen suosiona. (Ibid., 544-546.) Myös kansatieteilijä Juhani U. E. Lehtosen mukaan tällainen yleiskulttuuri muodostui konkreettiseksi tavoitteeksi, johon alemmat sosiaaliryhmät pyrkivät ja johon ne varallisuuserojen kaventuessa pääsivät (Lehtonen 1984, 594). Lopputulos oli pysyvämpi kuin luonteeltaan ailahteleva muoti, rationalismi tai ylhäältäpäin ohjattu tavoitehakuinen valistuspyrkimys. Mikrotason sähköistymisessä vaikuttivatkin paitsi sähkönostajien sisäsyntyinen halu päästä sähkönkäyttäjien joukkoon myös tarve järkeistää esimerkiksi raskasta maataloustyötä. Muutoksen taustalla siintävä motiivitavoite joustavoitti ja helpotti monia työtapoja ja vaikutti siten koko talonpoikaiseen elämäntapaan.

"Yläluokkaiset" ihanteet olivat siis monessa suhteessa ristiriitaisia perinteisen maalaisen perhemallin ja arjen kanssa, jossa "pöytä, piironki ja seinäkello edustivat kodin historiallisia arvoja ja nykyistä elämäntapaa" (Roos 1987, 78). Suurviljelijöiden, virkamiesten ja kaupunkilaisten johtama aatteellisuus ei heti kohdannut taloudellisesti ja sosiaalisesti eriarvoisia ihmisiä. Ylhäältäpäin toteutettu valistus- ja sähköpropaganda eivät tässä suhteessa toimineet 
toivotulla tavalla. Mikään ei voinut muuttaa arkista talonpoikaista elämäntapaa yhtäkkiä uudeksi, puhtaaksi ja hygieeniseksi. Sähköinvestoinnin kalleuden vuoksi kodeista tulikin ensi vaiheessa pelkästään valaistuja - ei tehokkaan teknisiä estradeja, joissa äidillä olisi ollut uudenlainen kodinhoidollinen rooli. Pikemminkin vähäiset hankintapäätökset sitoivat perheet entiseen tapaan maahan ja myöhemmässä vaiheessa iltaiseen televisionkatseluun. Oli tavallisempaa ostaa sähkömoottori tai lypsykone kuin kallis jääkaappi tai pulsaattoripesukone. Modernit kotitalousihanteet olivat selvästi sidoksissa sosiaaliseen asemaan, ikään ja varallisuuteen. Elämäntavan muutos liittyi syvemmän tason struktuurin muutokseen, jonka välittömiä - ja vain välittömiä - ilmifunktioita olivat sivistys, kilpailu, muoti, statusarvon nostaminen tai Marttaliikkeen ja Pellervo-Seuran kampanjointi.

\section{Imatralta kohti sähköistä Suomea}

Toista maailmansotaa edeltävä 1930-luku oli kaksijakoinen ja epätasapainoinen monessa eri suhteessa. Yleisesti talouden kasvu oli todella nopeaa, ja tavoitehakuisen talouspolitiikan tärkeimmäksi tavoitteeksi tuli maatalouden ja energiatuotannon omavaraisuuden kasvattaminen. Vesirakentaminen kuvasi muutosalttiutta, ja sen uskottiin edesauttavan myös maaseudun taloudellista kasvua. Monet päävesistömme Imatra mukaan lukien valjastettiin teollistuvan ja kaupungistuvan yhteiskunnan palvelukseen, ja laajeneva sähköverkko mahdollisti uuden energialähteen käytön pienemmissäkin yrityksissä. Imatran koskivoiman nähtiinkin olevan lähes itsenäisyyden mitta, sillä luonnonvarojen teknisen hyödyntämisen katsottiin osoittavan Suomen henkisen kehityksen astetta muihin maihin nähden. Asian ympärillä käyty keskustelu tiivistyi ilmaisuihin kansamme ylpeys, kansallinen rikkautemme ja Suomen luonnon suuri jättiläinen. Imatran valjastaminen oli suuri kansallinen projekti, jonka toteutuminen varmistettiin eduskunnassa vuonna 1921. Vajaa vuosikymmen myöhemmin alkanut Imatran jakaman sähkön aikakausi käänsi kokonaan uuden lehden sähkön jakelussa. Voimalinjat kulkivat läpi eteläisen Suomen, valtio tuki hanketta - ja mikä tärkeintä - se toteutettiin kansalaismyönteisessä ilmapiirissä 75\%:isesti kotimaisin voimin. (Herranen 1996, 11-12; Myllyntaus 1991, 79, 83.)

Toisaalta Suomi oli kuitenkin maatalousvaltainen maa. Harjoitettu maatalouspolitiikkakin tähtäsi Lex Kallion ja asutustoimintaa edistävien lakien avulla pienviljelijäluokan määrälliseen kasvattamiseen. Silti tuotetusta sähköstä noin $80 \%$ käytettiin teollisuudessa kotitalouksien osuuden jäädessä alle kymmeneen prosenttiin. Kaupungeissa henkeä kohti laskettu kulutus (138kWh) oli kolminkertainen maaseudun vastaavaan lukuarvoon verrattuna. Ja vaikka vuosittainen 14,1 \%:n kasvuvauhti oli eurooppalaisittain huippu- 
luokkaa, sähkönkulutus keskittyi Etelä-Suomen teollistuneille alueille. Juopa "maalaisköyhälistön" ja sähköä ostavien kotitalouksien välillä olikin suuri. Lisäksi koko yhteiskunnasta oli tullut osa modernistuvaa ja suhdannevaihteluille herkkää kansantaloutta. Tilapäisistä uitto- ja metsätöistä lisäansiota hankkineet pienet tilat elivät jatkuvassa taloudellisessa kurimuksessa. (Ahvenainen \& Kuusterä 1982, 228-248; Myllyntaus 1991, 45, 96-98; Salokangas 1987, 681-686; Sarparanta 1938, 369.)

Sähköistymisaalto taittuikin 1930-luvun alussa, kun maahamme levisi maailmanmarkkinoilta lama- ja pula-aika. Työväestöstä neljännes oli vailla työtä, ja heistä puolet oli pienviljelijöitä ja maataloustyöläisiä. Vasara kävi monella työpaikalla ja pientilalla, sillä lamasta eniten kärsineet saha- ja puunjalostusteollisuuden alat vähensivät tuotantoaan ja kavensivat siten pienviljelijöiden leipää. Ei siis ihme, että kiireellä perustetut sähkölaitoksetkin joutuivat vaikeuksiin. Edes vuosien 1934-1937 korkeasuhdanne ei ehtinyt korjata tilannetta, sillä vuosien 1939-1945 sotia edeltävä vakiintumisen kausi oli liian lyhyt. Tuloksena oli edelleenkin vain sähköinen, teollistunut ja kaupungistunut Etelä-Suomi. (Ahvenainen \& Vartiainen 1982, 186-187; Alapuro 1985, 80-85; Pylkkänen 1982, 32; Salokangas 1987, 681-686.)

Kaikkiaan 1930-luku oli Suomen elinkeino-oloissa kuitenkin lopullinen taitekohta, jolloin teollistuminen, kaupungistuminen ja uudenaikaistuminen konkretisoituivat aiheuttaen samalla dysfunktionaalisia ilmiöitä, $\mathrm{mm}$. maaltamuuttoa. Sosiologi Erkki Asp pitääkin 1920-luvun reformistisen kiihkeää ilmapiiriä näkyvänä kuorena, välittömänä ilmifunktiona jo 1800-luvulla alkaneesta muutoskehityksestä. Tekniikka ja reformiaate kulkivat ideologisen ja yhteiskunnallisen puolen edellä. 1920-lukuun kulminoituneen ja näkyvän muutoksen alla piili todellinen syvärakenteen muutos, joka puhkesi kukkaan vasta 1930-luvulla vallinneen kehitysoptimismin kautena. (Asp 1969, 27-28, $37-41.)^{3}$ On siis selvää, että tekninen kehitys yhdistyi suomalaisessa kontekstissa tapahtuneeseen asteittaiseen liberalisoitumiseen, modernisoitumiseen ja nationalistumiseen. Kehitys saavutti eri alueet hyvin eri tahdissa ja muodossa.

Toisen maailmansodan jälkeinen aika oli Suomen sähköistysolojen kannalta jälleen uuden vaiheen alku. Siirtokarjalaisten asuttaminen oli agraariyhteiskunnan sosiaalipolitiikkaa, joten kaikille halukkaille pyrittiin antamaan maata ja asunto. Jälleenrakennus ja asutustoiminta taas vauhdittivat maaseudun sähköistämistä. Lisäksi Neuvostoliitolle toimitettavat sotakorvaukset edellyttivät nopeaa voimantuotannon lisäämistä, varsinkin kun Suomi menetti sodassa 1/3 sähköntuotantokapasiteetistaan. Toisen maailmansodan jälkeinen

${ }^{3}$ 1930-luvun nousukausi johtui myös lähestyvästä sodasta, jota varten maailmalla ja Euroopassa valmistauduttiin kiireesti. Vrt. lisäksi Thomas Hughesin (1983) käyttämään termiin "technological momentum", joka kuvaa tekniikan omaksumisen vuorovaikutuksellista luonnetta, sekä Matti Räsäsen (1978) tulkintaan korkeasuhdanteen ja talonpoikaisen rahankäytön välisestä suhteesta. 
"teollistamisraivo" pakotti siis uuteen - ja uudenlaiseen - "sähköistämisraivoon". Motiivitaustat vain olivat erilaiset: 1920-luvun itsenäistyneen Suomen sisäsyntyinen halu vaihtui osittain ulkoapäin tulevaksi pakottavaksi tarpeeksi. Valitettavasti teollisuuden nopea kasvu osui yhteen huonojen vesivuosien kanssa. ${ }^{4}$ Luonnonolosuhteiden asettama pullonkaula johtikin tilapäisiin poikkeuslakeihin, valtiovallan säännöstelytoimiin ja pohjoisen jokien nopeaan valjastamiseen. 1930-luvun valaistuspropaganda muuttui vesipulavuosina Suomen Sähkölaitosyhdistyksen propagandaosaston toteuttamaksi säästökampanjoinniksi. (Haataja 1987, 748-749; Haavisto 1982, 37; Honkala 1966, 100 101, 136-137; Myllyntaus 1991, 101; Pihkala 1982, 349; Pylkkänen 1982, 32.)

Suomen maataloudessa työskenteli 1950-luvulla vielä yli kolmannes koko ammatissa työskentelevästä väestöstä. Maa- ja metsätalouden koneistuminen ja epävarmat luonnonolot kuitenkin altistivat maatalousväen teollisuuden tapaan suhdannevaihteluille: lohkotut pientilat eivät tarjonneet ympärivuotista toimeentuloa. Edes valtiovallan aktiiviset toimet paikallistason (sähkö)voimapolitiikan edistämiseksi eivät auttaneet. Pyrkimyksenä oli välttää pirstoutunutta ja reuna-alueita syrjivää sähköistämisstrategiaa, ja sähkö haluttiin valjastaa kasvattamaan maaseudun tuottavuutta. Sähkö nähtiin elämään tyytyväisyyden mittana. Optimistisimmissa visioissa tämän uskottiin vähentävän jopa maaltamuuttoa. Kupla kuitenkin puhkesi 1960-luvulla, jolloin patoutunut liikaväestö alkoi purkautua maaseudulta etelän kehittyville alueille. Osa muuttajista suuntasi Ruotsiin. (Granberg 1992, 56-57; Myllyntaus 1991, 108111; Pylkkänen 1982, 32-36; Salokangas 1987, 658-686.) Ei siis voi sanoa, että sähköistäminen oli harjoitetun agraaripolitiikan uskollinen renki, sillä laajat yhteiskunnalliset prosessit ajoivat vanhan yhteiskuntarakennelman ohi.

Suomi valitsikin 1950-luvulla kansainvälisen integraation tien. Maan talous tuli yhä riippuvaisemmaksi Euroopan ja koko maailman taloudellisesta kehityksestä, ja kansantalous kävi läpi taloushistoriansa ehkä suurimmat ja nopeimmat rakennemuutokset maatalousmaasta jälkiteollisiin elinkeinoihin ja maalaisasutuksesta kaupunkiyhteiskunnaksi. Viennin vapautuminen ja kotimarkkinateollisuuden tuotannon kasvu ja yleisen ostovoiman lisääntyminen saivat aikaan elintason yleisen nousun. Suomalaiset yritykset alkoivat vallata markkinoita lännestä, ja kuluttajien ulottuvilla oli ennennäkemätön määrä uusia hyödykkeitä - elintasokilpailu kiihtyi. Lisäksi muuttoliike Ruotsiin helpotti kotimaassa työllisyyden hoitoon kohdistuneita paineita. Ei siis ihme, että 1960luvulla saavutettiin tilanne, jolloin sähköistymisen edellytykset olivat oleellisesti paremmat kuin 15 vuotta aikaisemmin. Kansantalous oli paljon voimakkaammalla perustalla ja sähkönkäyttö lisääntynyt maaseudullakin. Sotien jäl-

\footnotetext{
${ }^{4}$ Vesivoima oli perinteinen ja lähes ainoa voimanlähde. Esimerkiksi 1950 -luvulla $90 \%$ tuotetusta sähköenergiasta saatiin koskien virtausvoimasta.
} 
keen perustetuilla sähkölaitoksilla oli vankka taloudellinen runkojärjestelmä, jonka turvin uuteen sähköistykseen voitiin soveltaa rajakustannusperiaatetta. (Pihkala 1982, 337; Pylkkänen 1982, 35; Vihavainen 1987, 863-865.)

\section{Paimiolainen menestystarina: Lounais-Suomen Sähkö-Osakeyhtiö}

Pioneerityön tekijöitä tarvittiin sähköistyksen kaikilla tasoilla. Lounais-Suomessa sijaitsevassa Paimiossa yleinen teknis-taloudellinen ja kulttuurinen edistys mahdollistivat kehityksen, jonka seurauksena paikalliset kutsuvat nykyistä kaupunkia Suomen sähköisimmäksi pitäjäksi.

Kunnan koko huomioon ottaen Suomesta ei löydy toista niin sähköistä kuntaa kuin Paimio. Monissa Suomen kaupungeissa on ollut ja on edelleen monipuolista sähköalaan liittyvää yritystoimintaa, mutta missään sähkö ei ole ollut niin keskeisessä asemassa kokonaisuuden kannalta kuin Paimiossa. Viime vuosikymmenen puolivälin tienoilla noin joka viides paimiolainen sai suoraan tai välillisesti toimeentulonsa sähköstä. (Itkonen 1989, 6.)

Menestystarinan ehdottomana edellytyksenä oli Paimionjoen virtaava koskivoima sekä itsenäisessä Suomessa vallinnut ilmapiiri, joka kannusti paikallisia innovaattoreita pioneerityön saralle: tekemään rohkeita, mielettömiä ja avarakatseisia päätöksiä. Sauvolais-karunalaisten kartanonisäntien jo vuonna 1910 perustama Karunan-Sauvon-Sähköosakeyhtiö oli sekä maamme ensimmäinen maaseutusähkölaitos - kuitenkin yhdessä Kurikan Jyllinkosken Sähkö-Osakeyhtiön kanssa - että Suomen "sähköistysraivon" kontekstia esimerkillisesti hyväksikäyttänyt yhtiö. Sähkölaitos oli Lounais-Suomen Sähkö-Osakeyhtiön (LSS Oy) edeltäjä ja alku sähköistämisen paimiolaiselle menestystarinalle. Yritys laajensi jakelukapasiteettiaan Paimionjoen varrelle, "[s]illä voimakysymys oli vaikeasti ratkaistava pulma, ja ennen kaikkea kaukosiirto ei tuntunut riittävän houkuttelevalta". (Haikala 1987, 10; Honkala 1966, 26; Rinne 1962, 10-12.)

\section{Karunan vuodet}

Sähkölaitosidea syntyi Sauvon-Karunan alueella jo vuoden 1910 tienoilla. Alkuvaiheessa laitoshanke oli eräänlaisen innovatiivisen sisärenkaan, kolmen kartanonisännän neuvottelufoorumi. Kerrotaankin, että isännät punnitsivat alkuvaiheessa jopa tuulimyllyjen kapasiteettia omaan tarpeeseensa tuotettavan energian lähteenä. Ponsi sähkövoiman käytölle syntyi vasta vähitellen, sanomalehtiuutisista sekä Turun sähkölaitoksen ja sähköraitiotien perustamisesta kertovasta pikkukirjasesta. Kyseessä oli uutuus, josta kukaan ei tiennyt 
oikein mitään. "Kesti jonkin aikaa ennen kuin asian tärkeys oli selvinnyt laajemmissa piireissä." (Haikala 1987, 10; Rinne 1962, 5-8.)

Sähkönjakelu ulottui ensi vaiheessa vain perustajajäsenten kartanoihin ja Sauvon kirkonkylään. Muuhun tuotettu energia ei olisi riittänytkään, sillä sähköä tuotettiin 150 hevosvoiman suuruisen halkokäyttöisen lokomobiilin avulla. Parinkymmenen kilometrin pituisen suurjänniteverkon kuluttama sähkö oli vuonna 1913 noin 55000 kilowattituntia, ja muuntamoita oli vain seitsemän kappaletta. Yhtiö oli myös pahasti velkaantunut, mikä asetti sen vaikeiden ratkaisujen eteen heti ensi metreillä: pysyäkö pienenä vai laajentaa tuotantokapasiteettia. (Haikala 1987, 12; Rinne 1962, 12-14.)

Jo varsin lyhyessä ajassa Karunan-Sauvon Sähkö-Osakeyhtiön johtohenkilöille oli selvinnyt, että toiminnan laajentaminen tulisi olemaan jatkuvan kehityksen ehdoton edellytys, ja varsinkin Paimio oli erikoisen huomion kohteena. (Rinne 1962, 17.)

Tuskin oli päästy alkua pidemmälle, kun jo paimiolaisten taholta ryhdyttiin neuvottelemaan sähköyhtiön kanssa. Johtokunta kokoontui tämän asia merkeissä heinäkuun 13. päivänä 1913 yhtiön konttorissa Maariankatu 2:ssa Turussa. (Ibid., 15.)

Tämä kaikki tapahtui aikana, jolloin maassamme elettiin romanttis-nationalistisen aatteellisuuden, kehitysoptimismin ja nousun kautta. Maariankatu 2:n päätös olikin aikakaudelle tyypillisen rohkea ja riskialtis. Se sopi varhaisen "sähköistysraivon" kontekstiin. Timo Myllyntauksen näkemys siitä, kuinka oli pieni ihme, että monet spontaanin päätöksenteon seurauksena syntyneet laitokset selvisivät, on varsin kuvaava LSS Oy:n varhaisvaiheiden kannalta. (Myllyntaus 1991, 267.) Maaseudulla täytyi olla todellinen halu sähköistyä ainoa syy, jonka keksin selitykseksi edelliselle.

\section{Tulo Paimioon: vaikeuksista voittoon}

Laitoksen historiassa käännetty uusi lehti sisälsi kuitenkin kaksi palstaa. Ensimmäiseen on kirjattu menestystarinan salaisuus, yhtiön rohkea askel eteenpäin. Toisessa taas kerrotaan riskeistä, siitä, miten yhtiö joutui vaikeuksien tielle. Tästä viitteenä oli jo toisena toimintavuonna otettu 90000 markan vekseli Turun Osakepankista. Yhtiö halusi näin taata toimintansa perusedellytykset ja teknisen valmiuden. (Rinne 1962, 18-19.) Laajenevan yhtiön tarpeet täyttävä koski oli ehkä tärkein syy sille, miksi juuri Paimio oli varhaisten sähköistäjien intresseissä. Alun perin laajenemista kaavailtiin Kemiön suuntaan. Jatkuva muutosalttius ja -halu olivatkin osoituksia kartanonisäntien innovatiivisuudesta. Kun käyttöön sopiva koski löytyi Paimionjoesta, Tarvasjoen Juvalta, Kemiö sai jäädä odottamaan vuoroaan. Yhtiö lähetti koskesta kirjelmän Senaatin talousosaston kamaritoimikunnalle vuonna 1913. Myöntävä 
päätös saatiin vuonna 1914, ja se astui voimaan 14.3.1915. Asian eteneminen byrokratiakoneistossa oli toimijoiden näkökulmasta kiusallisen hidasta. (Haikala 1987, 12-14.)

Samoihin aikoihin yhtiö rakensi ensimmäiset suurjännitelinjansa Rantolan voimalaitokselta Paimion kirkonkylään Vistalle. Ensimmäinen askel pois Sauvo-Karunasta oli konkreettinen tosiasia. Paimiossa laajeneva yhtiö sai myös historiansa ensimmäisen kilpailijan. Paimion Puutavara Oy:llä oli pieni sähkölaitos, joka tuotti virtaa rautatieaseman ympäristöön. (Innamaa 1973, 688689; Haikala 1987, 12.) Linjanvedolla olikin symboliarvoa: yhtiö sai kilpailijan, jonka kanssa oli neuvoteltava ehdoista.

Kaikkiaan yhtiö oli jo 1910-luvulla voimakkaan laajenemisen tiellä. Sillä tiellä se myös pysyi. Toisaalta ensimmäisen maailmansodan kriisi vei yhtiön rahavaikeuksiin. Osakemerkintä ei onnistunut odotettuun tapaan, materiaalista oli pulaa ja rahalaitokset olivat pidättyväisiä lainanjaossa. Lisäksi kilpailevan Maarian Sähkö-Osakeyhtiön kanssa jouduttiin ratkomaan etu- ja yhteistoimintakysymyksiä sekä keskinäisiä sähkön myynti- ja ostokysymyksiä. 1910luku olikin vaiherikas toimintamuotojen hakukausi. Tämä näkyi varsinkin yhtiön johdossa, jossa nopea vaihtuvuus oli enemmän sääntö kuin poikkeus. Juvankosken vuokraaminen ja uuden voimalaitoksen rakentaminen oli yhtiön jatkon kannalta kuitenkin ratkaiseva päätös. Se oli käänne parempaan, sillä Rantolan kallista sähköä tuottanut höyryvoimala myytiin ja sähkönkulutuksen kasvun myötä rahaa jäi säästöön ensi kerran koko yhtiön historiassa. En-

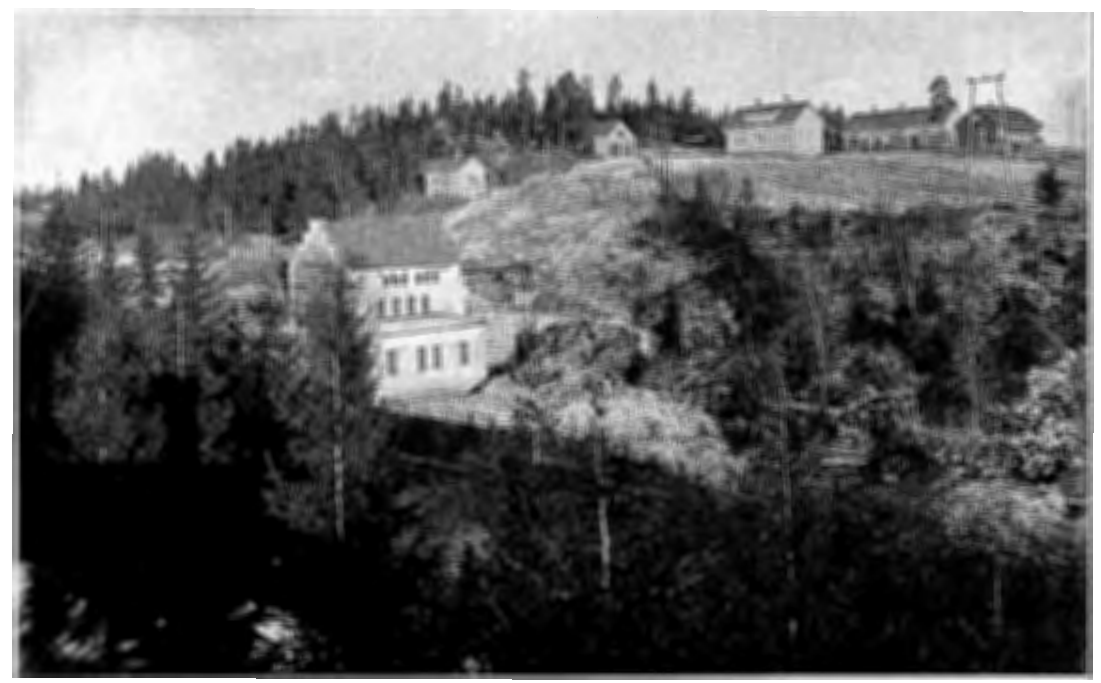

Lounais-Suomen Sähkö-Osakeyhtiön 1930-luvulla rakentama voimalaitos Paimion Juntolassa. Kuva: Paimion Sähkömuseo. 
simmäiset osingot jaettiinkin vuonna 1918. (Haikala 1987, 14-16; Innamaa 1973, 689; Rinne 1962, 22-28.)

LSS Oy kuului ensimmäisen maailmansodan jälkeisiin voittajiin. Kriisivuosien 1914-1918 jälkeen yhtiö pääsi osalliseksi sodan jälkeisen nopean kasvun kaudesta. Jatkuvasti lisääntyvä sähkön kysyntä johti pian lisävoiman tarpeeseen. Sopiva kohde löytyi sopivasti Paimionjoen alajuoksulta, vain muutamien kilometrien päästä Juntolasta. Koski oli palvelut jo 1700-luvulla sahateollisuutta ja toimi lyhyen ajan myös myllyn voimanlähteenä. 12,5 metriä korkea Askalan koskivoimala liitettiin yhtiön verkostoon vielä vuonna 1936, joten Paimionjokivarressa oli ennen 1940-lukua jo kolme LSS Oy:n omistamaa sähkövoimalaitosta. Niiden yhteenlaskettu koneteho oli 3530 turbiinihevosvoimaa, mistä Askalan ja Juntolan osuudet olivat kummankin 1400 hevosvoimaa ja Juvan 730 hevosvoimaa. Lisäksi yhtiö rakennutti (1939) Mynämäen Laajoen Korvensuuhun 400 hevosvoiman voima-aseman. (Innamaa 1973, 689-690; Rinne 1962, 40-44; Santala 1962, 43; Turun Sanomat 1962, 11.)

Lukuisten fuusioiden ja konkurssien jälkeen kasvavaan yhtiöön liitettiin monia toimivia maaseutusähkölaitoksia, sillä 1910-luvun "sähköistysraivon" seurauksena kovalla kiireellä perustetut pieniresurssiset laitokset ajautuivat yksi kerrallaan konkurssiin (ks. Sarparanta 1938 edellä). Liitettyihin voima-

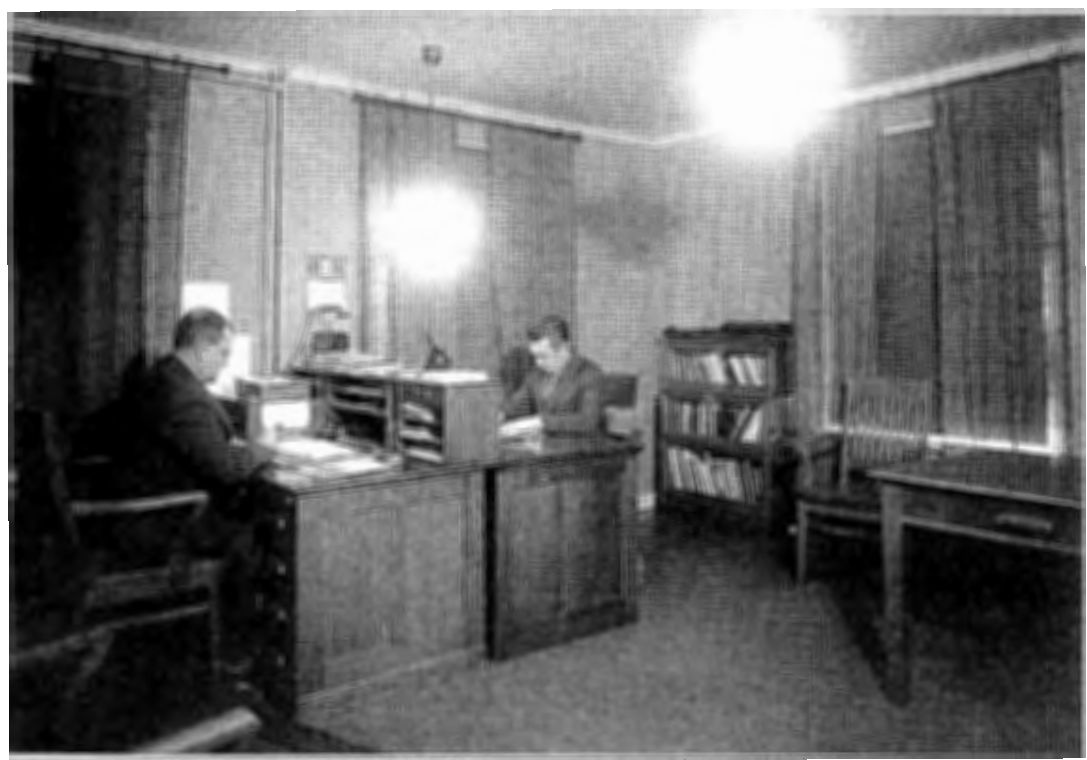

Lounais-Suomen Sähkö-Osakeyhtiön toimistohuone Paimion Vistalla vuonna 1933. Kuvassa konttoripäällikkö Haapala ja insinööri Tuominen. Kuva: Paimion Sähkömuseo. 
loihin kuuluivat mm. Halikon Sähkö Oy (1924), Varsinais-Suomen Sähkö Oy (1927) sekä Vinkkilän Mylly ja Kauppa Oy (1929). Vakka-Suomen Sähkö Oy:n osake-enemmistö siirtyi yhtiölle vähitellen vuosina 1935-1936. 1930luvun pahojen lamavuosien seurauksena yhtiöön liitettiin myös sen varhaisvuosien pahin kilpailija, pastori J. R. Ellilän Maarian Sähkö Oy (ks. maininta edellä). Maarian Sähkö Oy:n vaikeudet kuvaavat lamavuosien oloja kaikessa raadollisuudessaan, sillä Maarian "sähköpastoriksi" nimetty J. R. Ellilä oli yksi keskeisimmistä "sähköistysraivon" rationalisoinnin puolestapuhujista. Hän korosti valistus- ja neuvontatyön tärkeyttä sekä varoitti sähköntuottajia vilpillisistä sähköliikkeistä ja yrittäjistä, jotka käyttivät hyväkseen uutuuteen liittyvää tietämättömyyttä. (Haikala 1987, 17-26; Honkala 1966, 32; Rinne 1962, 42-44; Turun Sanomat 1962, 11.)

\section{Lopputulos: maakunnan monopoli}

Toinen maailmansota ei katkaissut LSS Oy:n sähkönjakelua. Materiaali- ja työvoimapula olivat kuitenkin vakavana ongelmana, sillä sähkön tarve ja kulutus kasvoivat jatkuvasti. Erilaiset hätäratkaisut, mm. korvikemateriaalien käyttö, olivat sotavuosien arkea: "Kaapelitehdas alkoi käyttää tervalla kyllästettyä kuparirimpsua, joka kierrettiin kuparilangan ympärille. [..] Rautalankaa taas käytettiin linjoissa." (SMH 1996, MR.) Tilanne palautuikin ennalleen vasta vähitellen. Kuparin säännöstelystä luovuttiin 1940-luvun lopussa, mutta käyttöä rajoittavaa "sähköpropagandaa" jatkettiin vielä 1950-luvullakin. (Haikala 1987, 27-28; Rinne 1962, 73-77; TYKL. Fingerroos 1998, 4.)

Yleiset asenteet sähköä kohtaan olivat sodan jälkeen kuitenkin myönteisiä. Sähköön oli totuttu ja sitä vaadittiin. Oman lisänsä kasvavalle kysynnälle toivat Varsinais-Suomeen sijoitetut karjalaiset siirtolaiset. Tilanteen rauhoittuminen merkitsikin sähköistäjille taattuja markkinoita: "[S]illoin sodan jälkeen [..] tiesi tekevänsä jotakin, ku [..] sai viedä sähkön semmoseen paikkaan, missä sitä ei enne ollu. Siinä tunsi kyllä tekevänsä jottaa hyvää." (SMH 1996, MR.)

LSS Oy nostaa historiastaan mielellään esille 1940-luvulla alkaneen ja yhtiön modernisointiin kuuluneen tariffiuudistuksen ikään kuin nousun avaimena. Tariffiuudistuksella haluttiin kannustaa kuluttajia sähkön käyttöön: uuden tariffin perustana oli asuinhuoneistojen lukumäärä, maanviljelyksessä peltopinta-ala, julkisissa rakennuksissa lattiapinta-ala ja ammatinharjoittamisessa moottorien liittymisteho. Yhtiö peri perusmaksuna tariffiyksiköltä 400 markkaa vuodessa ja kulutuksen mukaan määräytyvän erillisen kilowattituntimaksun. Uudistus oli mittava, ja siihen saatiin Maaseudun Sähköyhtymien Liitolta hyväksyvä lausunto vuonna 1949. Tiedottaminen hoidettiin näyttävästi lehtisten "Otamme tärkeän askeleen" ja "Tariffin" avulla - säännöstely- 
propagandan aika oli siis jo ohi. Yhtiö teki samalla myös valtakunnallista sähköhistoriaa ja pioneerityötä, sillä valmiiksi räätälöity tariffimalli toteutettiin valtakunnan tasolla 1950-luvulla. (Haikala 1987, 30; Herranen 1996, 136, 148, 167; Rinne 1962, 78-80; TKU/A/96/37.)

Se, mikä kannatti ja oli sähköistäjien mielestä rationaalista, ei miellyttänyt maksajina toimineita kuluttajia. LSS Oy kokikin historiansa värikkäimmän vaiheen kehittäessään sähkölinjojaan. Rationalisointi kulminoitui 1950-luvun lopussa käynnistyneeseen pienjänniteverkkojen ja yksityisten muuntopiirien kunnostukseen. Ne olivat vaihtelevassa kunnossa ja liian pieniresurssisia kannattavaan sähköntuotantoon. Yhtiö näki ainoana järkevänä vaihtoehtona yhtenäisen kehitysstrategian, muuntopiirien vapaan luovutuksen. Se ei katsonut velvollisuudekseen vastaanottaa huonokuntoisia verkkoja ilman korvausta. Toiminta oli kuluttajan näkökulmasta kuitenkin epäoikeudenmukaista. Muuntopiirien ja linjojen kunnostusmaksut nähtiin pienyrittäjien riistona ja maaseudun kehityksen esteenä. Yhtiön toimintatavoista käytiinkin keskustelua varsinkin aatteellisten lehtien palstoilla.

\section{Huimia kilowattihintoja maaseudun sähköyhtiöille Sähköpolitiikka epäedullista pienkuluttajille}

Lounais-Suomen Sähköyhtiön Turun puolesta tunnemme paremmitta esittelyittä ja muistamme sen komeat toimitilat Paimiossa sekä sen, miten sopimuksen aukkopaikan takia yhtiö perii jokaisesta Turkuun välittämästä kilowattitunnista ylimääräisen markan. Näin kertyvät vuotuiset miljoonat maksavat tietenkin kuluttajat.

(Uusi Päivä 1960, 6)

LSS Oy:n kannalta uudistukset olivat kuitenkin välttämättömiä. Sisko Haikala kirjoittaakin yhtiön historiikissa, että päätökset tehtiin yhdennellätoista hetkellä, sillä yritys oli jäänyt 1950-luvulla maamme sähkölaitosten yleisestä kehityksestä. Ilman pienjänniteverkon peruskorjausta yhtiö ei olisi kyennyt vastaamaan sähkönkysynnän ekspansioon. (Haikala 1987, 39.) Käytännössä "kova homma" lankesi muutamalle yhtiön edustajalle. Eräskin koki olleensa muuntopiirien lunastuksessa "vähän liiankin konkreettisesti" mukana:

Koskellakkii minä sanoin, et mää taian vaihtaa firmaa peevel, ku ne rupes haukkumaa jo henkilökohtasest. [..] Tää koskelainen mentaliteetti on semmonen, et kaikki täytyy omistaa itte, ei mitään yhteistä. [..] Ja sit pidettiin hirveenä omaisuutena tätä muuntopiirin omistusta: nyt annetaa monopolil valta, et kauhjat omaisuuvet joutuu yhtiöl antamaa ja sit joutuu viel maksamaa. [..] Kosken isäntämiehet, ne organisoit tänne semmosen kuntakokouksenki [..], siin oli Somero ja Mellilä ja Karinainen ja Marttila ja tais Kuusjokikii ol mukan, et ne perustaa oman sähkölaitoksen. Muistan, ko [..] oltii, ni yks kaverikii siin eteises sano, et mä ostan Lounais-Suomen Sähkö, eiks se sovi, mä annan markan, ni mä ostan koko Lounais-Suomen Sähkön. Et tämmöst puol haukkumista oli. [..] Me oltiin niin ku altavastaajan. Isäntämiehii vissii kakskyt kappaletta - jos riittikää! (TKU/A/90/36.) 
Erilaiset konfliktitilanteet olivat sähkömiesten näkökulmasta kiusallisia mutta väistämättömiä - varsinkin kun raha oli yleisin riidan aihe. Erilaiset sovitteluratkaisut olivatkin tarpeen: kun yhden maksuja alennettiin, piti toisen maksuja lisätä. Väärinkäytöksiä puitiin luonnollisesti käräjillä, sillä sähkömies toimi aina yhtiön edun nimissä. Epärehelliset asiakkaat olivat kekseliäitä. Joku porasi mittarinlukijaan reiän ja asensi levyjarrun, toinen käytti vahvaa magneettia ja kolmas väänsi kolmivaihemittaria kaksi vaihetta taaksepäin, jolloin mittari luki vain yhden vaiheen. Viljelijät käyttivät hyväkseen hitsaustaitoaan. Vaarallisimpiin kuulunut yksittäinen tapaus sattui Kuusjoella, jossa erään myllynomistajan poika sekosi ja kävi äitinsä ja sisarensa yllytyksestä mittaria lukeva sähkömiehen kimppuun. Arkisempaan dramatiikkaan syyllistyivät talojen vihaiset vahtikoirat. (TKU/A/90/40.)

1960-luvulle tultaessa LSS Oy:stä oli kehittynyt "maakunnan monopoli", joka työllisti 64 henkilöä ja jakoi sähköä 52 kunnan alueella Varsinais-Suomessa. Paikallisten pioneerien aika oli kääntynyt maakunnallisen yrittäjyyden ajaksi. Vanhojen veteraanien väistymistä voidaankin pitää saavutetun "uuden" sähköisen ajan symbolina. Yhtiön viimeinen perustajajäsen, Otto Rotkirch, kuoli vuonna 1960. (Haikala 1987, 31-32, 40.)

\section{Toinen paikallinen menestystarina: SähköLähteenmäki Oy}

\section{"Iso-Iivari" Lähteenmäki}

Toimintaansa jatkuvasti laajentanut Lounais-Suomen Sähkö-Osakeyhtiö loi edellytyksen myös toiselle paikalliselle menestystarinalle, sillä sähköntuottajalle oli edullista saada yhteistyökumppaniksi sähköurakoitsija mahdollisimman läheltä. Apu löytyi yhtiön uudesta kotikunnasta, sillä paimiolaisen työläisperheen poika Iivari Hemming Lähteenmäki sai vuonna 1920 ensi kosketuksen aikakauden innovaatioon haravoidessaan lehtiä Lounais-Suomen Sähkö-Osakeyhtiön johtajan puutarhassa. Iivari Lähteenmäki oli oppinut kotikasvatuksen kautta, että ihmisen on tehtävä ahkerasti työtä. Hänellä olikin 19-vuotiaana paitsi yhdeksän vuoden työkokemus myös peräänantamaton luonne, geenien kautta peritty suuri koko ja työnteon kautta hankittu fyysinen voima. Mieheksi nuorukainen varttui monen ikätoverinsa tavoin Suomen sisällissodan vuosina: kaksi vuotta kestäneellä pakomatkalla, joka johti Hennalan (Lahti) ja Poltinahon (Hämeenlinna) kautta Turun punavankileirille. (Kalpa 1973, 20; SMH 1996, JL.)

Suurikokoisen "Iso-Iivarin" poikkeukselliset ominaisuudet auttoivat häntä urallaan nopeasti eteenpäin. Hän siirtyi ensin LSS Oy:n linjaporukkaan tötsästämään eli kaivamaan tolpanreikiä. Tehokkaana sähköpylväiden pystyttäjänä hän oli pian koko linjaporukan etumies. "Iso-Iivari"' haistoi myös maa- 
seudun sähköistämisen tarjoaman mahdollisuuden työllistyä. Iivari Lähteenmäen poika Jukka Lähteenmäki onkin luonnehtinut isäänsä luontaiseksi riskinottajaksi ja johtajaksi, joka opetteli ja opiskeli itse. Ei siis ihme, että tötsäpojan teki mieli oikean monttöörin oppiin. Sopiva tilaisuus koitti vuonna 1921, kun insinööritoimisto Palmgren rakensi Turun Halisiin vesilaitosta. Iivari sanoutui irti LSS Oy:n linjaporukasta, matkusti Turkuun ja oppi tekemään sähkötöitä. Iltaisin ja viikonloppuisin hän sähköisti oppi-isänsä Aku Suomisen kanssa Halisten ja Paaskunnan torppia. (Kalpa 1973, 23; SMH 1996, JL.)

Harri Kalpa kirjoitti SähköLähteenmäki Oy:n (SLM) 50-vuotisen taipaleen kunniaksi vuonna 1973, että "noiden kuudentoista kuukauden aikana Iivari oli pannut merkille, miten sähkömiestä arvostetaan. Se olisi huomispäivän ala, ala, jolla olisi tulevaisuus." (Kalpa 1973, 26.) Ajatuksen oman yrityksen perustamisesta täytyi kypsyä siis viimeistään Turussa vietetyn puolentoista vuoden aikana. Nopea päätös yrittäjäksi ryhtymisestä toteutuikin vuonna 1923 - aikana, jolloin maaseutua ruvettiin sähköistämään. (Kalpa 1973, 23; SMH 1996, JL.)

\section{Tolppakengistä kauppaneuvoksen aikaan}

Iivari Lähteenmäen yrittäjän ura lähti etenemään suotuisissa merkeissä. Hyvälle ja oppia saaneelle sähkömiehelle riitti asennustöitä alusta saakka runsaasti. "Kylä kylältä, talo talolta Iivari Lähteenmäki toi sähkön paimiolaisiin koteihin." Jokelan koulu oli varhaisvaiheen ensimmäinen suuri urakka, jota Lähteenmäki ei kyennyt suorittamaan enää yksin. Ympärille kertyikin varhaisten monttöörien eli tolppakenkäveljien ryhmä. Tämä ydinjoukko koulutti Paimioon myöhemmin kokonaisen asentajasukupolven. On jopa sanottu, että Iivari ja hänen tolppakenkäveljensä sähköistivät koko Paimion. (Kalpa 1973, 28-31; Uittomäki 1997a, 6).

Tolppakenkäveljeksiä on vasta jälkeenpäin ruvennut mietityttämään, miten totisen kova paikka maaseudun sähköistäminen oikeastaan oli - puolin ja toisin. Pienelle torpalle sähkön hankkiminen mahtoi tuottaa taloudellista huolta vuosiksi. Tuskin tuntui torpparista turvalliselta mennä lakkiaan pyöritellen nöyränä poikana anomaan pankista sähköistämislainaa. Niitäkin tapauksia tiedetään, miten yliylpeä pankinjohtaja syrjäkulman miehelle ihmetteli ääneen kaupunkivalojen tarpeellisuutta. (Rantala 1993, 8.)

Vaatimatonta oli se varustelutaso. Valopisteet laskettiin tarkasti; yksi kyökkiin, toinen kamariin, ulkovalo porstuaan ja viimeinen tuikku navettaan. [..] Nykyajan ihminen ei millään pysty tajuamaan, miten arvokkaaksi sähkö koettiin. Vaikka se hankittiin, samalla sitä säästettiin. (Ibid.)

Asentajan arvostuksen korkein aste koettiin silloin kun maalaistaloon ruvettiin piuhoja koplaamaan. Usein sattui, että isännälle ja emännälle juh- 
kaantui sanaharkkaa nappuloiden paikasta. Yleensä riita ratkesi emännän ärjäistyä: "Kyl sähkömies sen paremmin tietää!" (Ibid.)

SähköLähteenmäki Oy (SLM) on jakanut historiansa ennen 1960-lukua kahteen eri vaiheeseen: pioneerivaiheeseen ja monipuolistumisen vaiheeseen. 1960-luku oli kasvun kautta, 1970-luku jopa vauhtisokeuden aikaa. Pioneerivaihe sijoittuu liikkeen perustamisesta (1923) 1950-luvun taitteeseen (1949) ulottuvaan aikahaarukkaan. Tänä aikana yhtiö sai ensimmäisen oman kiinteistönsä (1936) ja oikeuden suorittaa vaativia A-ryhmän asennustöitä maaseudulla (1949). Pioneerivaiheen merkittävin käännös oli kuitenkin vuonna 1930 aloitettu saariston sähköistys, joka alkoi Kemiön saaresta. Asentaja Martti Rantanen muisteleekin, että suurin osa Lähteenmäen työmiehistä oli tällöin Kemiössä. Työmaalla oltiin viikko ja välillä kauemminkin. Maanantaiaamuna kello seitsemän kokoonnuttiin Lähteenmäen verstaalle työnjakoon. Sieltä jatkettiin polkupyörällä Sauvontien varteen odottamaan linja-autoa. Dragsfjärdin osuuskaupan pysäkiltä jatkettiin polkupyörällä edelleen Kemiöön. Yhtiön vuonna 1936 hankkima auto tuli siis tarpeeseen. (ABB Linkki 1993, 12; Kalpa 1973, 24, 40; SMH 1996, JL; SMH 1996, MR; Stöpseli 1983, 5-7.)

Päätös vaativan saariston sähköistysurakan vastaanottamisesta oli jatkon kannalta merkittävä, sillä siitä alkoi kehitys vähäisestä sähköurakoitsijasta suureksi asennusliikkeeksi. Kasvun ja monipuolistumisen merkkinä voi pitää ennen kaikkea sitä, että Iivari Lähteenmäki siirtyi kokonaan Kemiön urakan koordinoijaksi. Työnjohtajaksi Paimioon jäi hänen luottotyöntekijänsä Olavi Rantanen. 1950-luvulla yrityksen palvelukseen tuli myös ensimmäinen sähköinsinööri. Perinteinen järjestelmä murtui; "Iso-Iivarin" ja tolppakenkäveljien väliin tulivat "indessit ja insinöörit" tuntikortteineen ja kirjallisine työmääräyksineen. Kesti pitkään ennen kuin uuden tilanteen aiheuttama pato murtui - olihan Iivari Lähteenmäki linjamiesten apuna ajoittain vielä Kemiössäkin. (ABB Linkki 1993, 13; Kalpa 1973, 38-39, 56, 64, 70-71; Stöpseli 1983, 7-9.)

SLM avasi 1950-luvulla oman sähkötarvikkeita myyvän liikkeen ja kehitti oman peltirakenteisen jakokeskuksen. Vuosikymmen merkitsi myös saariston lopullista sähköistymistä, sillä viimeisenä suoritettu Särkisalon ulkosaarten Petun ja Utön urakka valmistui juuri 1960 luvun kynnyksellä (1958-1959). Varsinkin vuonna 1955 aloitettu peltirakenteisten jakokeskusten kokoaminen laajeni nopeasti omasta käytöstä myös ulkopuoliseen myyntiin. Jakokeskuksille syntyi sopiva markkinarako, sillä SLM oli Turun alueen ainoa keskusvalmistaja. Kun liike panosti jatkuvaan omalla kentällä suoritettavaan tuotekehittelyyn ja lyhyisiin toimitusaikoihin, se pystyi valtaamaan markkinat itselleen. Perinteiseen toimenkuvaan kuuluneet asennus- ja myyntitoiminta saivat nyt rinnalleen uuden osa-alueen. Teollisuustoimintaan siirtyminen olikin seuraava suuri askel ja osoitus liikkeen innovatiivisuudesta. (ABB Linkki 1993, 13; Kalpa 1973, 79-81; Stöpseli 1983, 7-9.) 


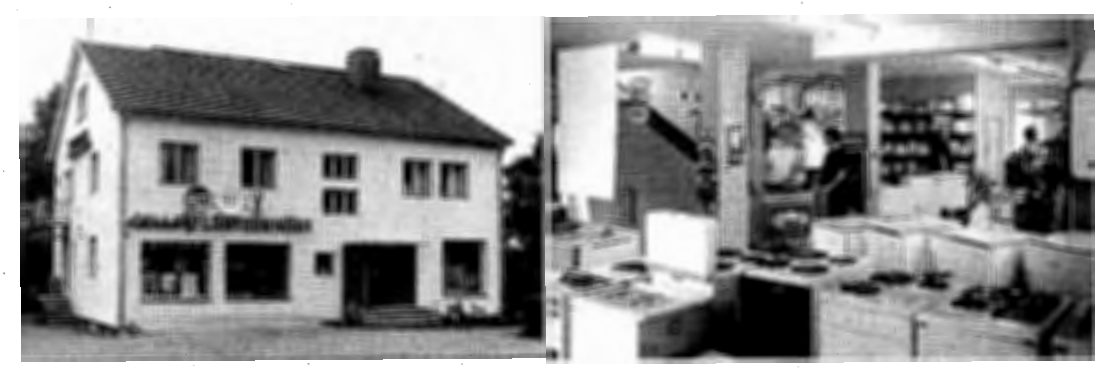

SähköLähteenmäki Oy:n konttori- ja myymälärakennus sekä myymälä sisältä. Kuvat: Paimion Sähkömuseo

SähköLähteenmäen lopullinen siirtyminen valtakunnalliseksi asennusliikkeeksi tapahtui viimeistään kuusikymmenluvulle tultaessa. Kun maassamme havaittiin ensimmäiset tulevan laskusuhdanteen merkit, SLM siirtyi suurteollisuuden ja Turun yliopistollisen keskussairaalan kaltaisiin vaativiin työkohteisiin. Uuden tehtaan (tosin järjestyksessä jo kolmas tehdastila) rakentaminen ja valmistuminen (1968) osuivat siis keskelle laskusuhdannetta. Ei ihme, että monet paikalliset leimasivat hankkeen mielettömäksi. Toimi olikin osoitus Iivari Lähteenmäen riskinottokyvystä ja tulevaisuuteen suuntautuneesta innovatiivisuudesta. Rakentaminen oli laman aikana edullista, ja tuotantolaitos valmistui sopivasti korkeasuhdanteen kynnyksellä. (Kalpa 1973, 34.)

Vuoden 1968 urakka oli Iivari Lähteenmäen viimeinen ns. virallinen toimi liikkeenjohtajana. Hän siirtyi sen jälkeen muodollisesti eläkkeelle. Tasavallan presidentti nimitti hänet samana vuonna kauppaneuvokseksi. Liikkeen johto siirtyi isältä pojalle, Jukka Lähteenmäelle. (ABB Linkki 1993, 13; SMH 1996, JL; Stöpseli 1983, 11.)

Veikko Anttila on todennut, että pienyhteisöä koskevassa sosioekonomisessa tutkimuksessa on pidettävä etualalla innovaattoreiden, omaksujien ja torjujien sosioekonomista statusta. Tyypillisen talonpoikaisyhteisön innovaattorin tuntomerkkeinä hän luettelee mm. yhteisössä saavutetun korkean statuksen, kommunikointikyvyn, yleis- ja ammattikoulutuksen sekä varallisuuden. Innovaattorilla on myös kyky muuttaa vanha traditio, sillä hänellä on siihen tarvittavaa rohkeutta ja kokemusvarastoa; hän kulkee epäsuoran industralisaation etujoukossa. (Anttila 1976, 11.) Iivari Lähteenmäki oli selkeä innovaattori Paimiossa. Hän koulutti itsensä sähkömieheksi, omasi poikkeuksellisia johtajanominaisuuksia ja käytti luontaista rohkeuttaan perustaessaan oman yrityksen. Taustalta löytyi myös vaimo, Anni Lähteenmäki, joka toimi tarpeellisena taustatukena, kuten Jukka Lähteenmäki kuvaa:

Mä olen selittänyt aina firman historian niin, et [..] isä oli tämmöinen valloittaja ja etenijä ja äiti tuli perässä ja huolehti, että kaikki pysyy kunnossa. [..] Et jos äitii ei olis ollu, olis voinu käydä hullummin. [..] Hän piti langat käsissä. (SMH 1996, JL.) 
Lähteenmäki oli myös paikkakuntalaisten tuntema monttööri, joka kykeni pystyttämään sähkötolpan yksinään sekä oli nopea ja ulottuva sisäasentaja. Lisäksi hänellä oli Halisten ja Paaskunnan torpissa hankittu käytännön työkokemus. Asetelmasta puuttui vain Veikko Anttilan mainitsema talonpoikainen varallisuus. Sitä työläisperheen pojalla ei luonnollisesti ollut. Pääomaa kertyi vasta vähitellen. Välittömän rahantarpeen korvasi markkinarako eli sähkön kasvava kysyntä ja hyvä ajoitus. (Kalpa 1973, 28; SMH 1996, JL; Uittomäki 1997a, 5.)

Lähteenmäen innovatiivisuuden taustalla piili kolme esiteollisen industrialisaation eli sähköisen asennemuutoksen ja "sähköistysraivon" edellytystä: (1) Paimionjoki, (2) sähköä tuottava LSS Oy sekä (3) LSS Oy:n ja paimiolaisten luoma kysyntä eli erinomainen markkinarako. Varsinkin LSS Oy lisäsi vastaperustetun liikkeen vakautta, sillä yhtiöllä ei ollut ennen sotaa lainkaan omia linjamiehiä. Jukka Lähteenmäki tiivistääkin isänsä menestyksen salaisuuden yhteen lauseeseen: "Hän oli oikeassa paikassa oikeaan aikaan." (SMH 1996, JL.)

Paikallisena työllistäjänä ja sähköisen imagon luojana "Iso-Iivari" oli melkein "legenda jo eläessään". Paimiolaisten keskuudessa Iivari Lähteenmäellä onkin lähes myyttinen asema. Hänestä kerrotaan monenlaisia juttuja, jotka täyttävät folkloren tunnusmerkit. Eräs sodan jälkeistä aikaa kuvaava karikatyyri löytyy esimerkiksi sanomalehti Johannekselaisesta. Lehden mukaan jonkinmoista arvostusta osoitti Paimion siirtokarjalaisten iltarukous: "Hyvä Luoja. Varjelethan sie meittii Paimion Sahalta, Värtsilän pajalta ja Lähteenmäeltä." (Rantala 1993, 8.) Toimittaja Kari Uittomäki toteaakin täysin aiheesta, että Iivari Lähteenmäessä on ainesta jopa kirjaa varten. "Iso-Iivarin kautta olisi helppo peilata Suomen koko 1900-luvun historiaa." (Uittomäki 1997b, 4.)

Vanhoille työmiehilleen kauppaneuvos pysyi loppuun saakka isällisenä "IsoIivarina", joka aloitti tavallisena asennusmiehenä ja koulutti varhaisten tolppakenkäveljiensä kanssa Paimioon kokonaisen asentajasukupolven. Martti Rantanen ja Paavo Sahlström ovat tyypillisiä Lähteenmäen jo eläkkeelle jääneitä veteraaneja. Edellinen oli 1930-luvun laman taittuessa 17-vuotias poika vailla kunnollista työpaikkaa. Ratamestari Holmströmin huvilasta alkanut apupojan tie vei Piikkiön, Kaarinan, Kuusiston, Kemiön saaren, Someron, Kuusjoen ja Kiikalan kautta aina Vihtiin ja Alavudelle saakka. Jälkimmäinen sai pestin heti sotien 1939-1945 jälkeen - ensimmäisenä toipumislomapäivänä. Yli 40-vuotta kestänyt ura alkoi niin ikään sisäasennuksista isomman veljen, Armas Sahlströmin, opastuksella: "Se oli hyvä paikka. Sinne mentiin, sinne pääsi ja sinne jäätiin." (SMH 1996, MR; SMH 1996, PS.)

Täydellä syyllä voi siis sanoa, että firma oli osa sekä Iivari Lähteenmäkeä että suomalaisen yhteiskunnan 1900-luvun muutosta ja paimiolaisuutta. IsoIivarin poika Jukka Lähteenmäki luonnehtii isänsä luomaa yritystä myös oman elämänsä sisällöksi, intuitioon ja taiteeseen verrattavaksi luomukseksi, jonka attribuuteiksi sopivat kasvu, kehittäminen ja paimiolaisuus: "Paimiolaisuus 


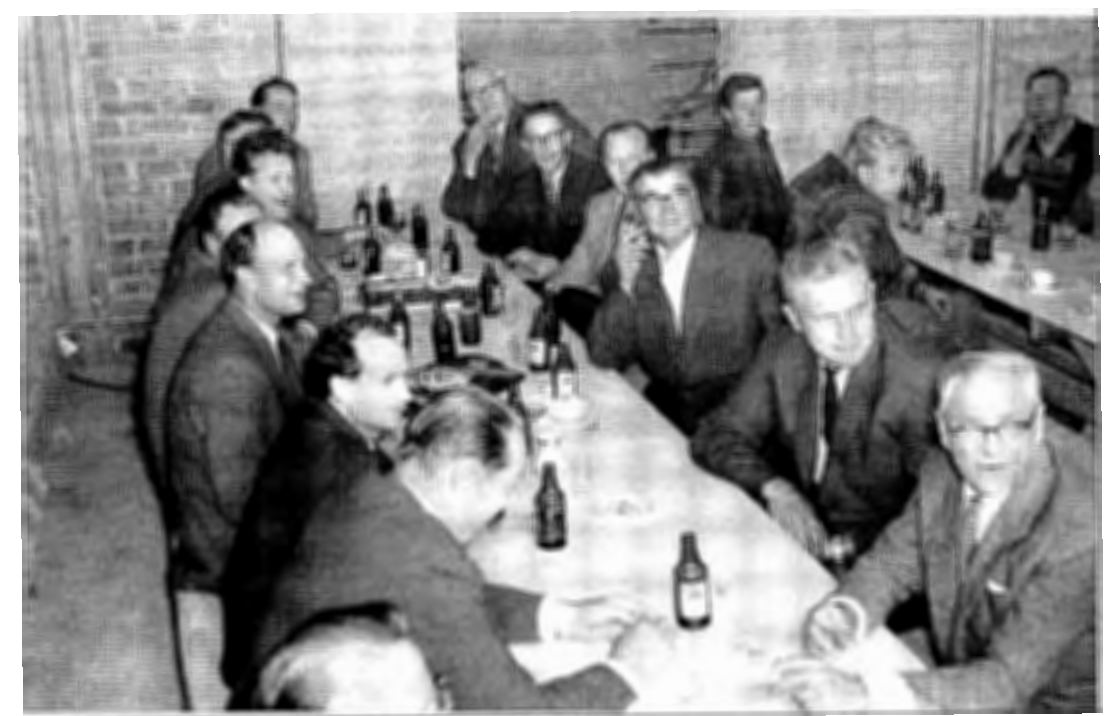

"Iso-Iivari" joukkoineen viettämässä iltaa KOP:n harjannostajaisissa Paimiossa vuonna 1959. Iso-Iivari istuu seinän vieressä keskellä. Kuva: Paimion Sähkömuseo

merkitsee enemmän kuin numerot: kotikunta ja kehitys, autorivi parkkipaikalla." (SMH 1996, JL.) Samaan tapaan ajattelee enemmistö paimiolaisista, sillä Iivari Lähteenmäki äänestettiin vuoden 2000 alussa vuosisadan merkittävimmäksi paikalliseksi vaikuttajaksi.

\section{Miksi juuri Paimio?}

Paimion vaiheet liittyvät olennaisella tavalla koko valtakunnan 1900-luvun yleiseen muutoskehitykseen. Valtakunnantason kehityksen asettamat teknistaloudelliset ja kulttuuriset reunaehdot mahdollistivat paikallistason sähköisen kehityskaaren, jonka ehdottomana edellytyksenä oli Paimionjoen virtaava koskivoima. Joki loi pitäjän sähköistymiskehitykselle ekologiset reunaehdot, jota paikallista pioneerityötä ja valtakunnallista sähköhistoriaa tehneet sauvolais-karunalaiset kartanonisännät ymmärsivät hyödyntää. (Ks. kaavio 1) Suomen ensimmäinen maaseutusähkölaitos syntyi joen varteen ja kasvoi. Yhtiö teki aikakauden "sähköistysraivoa" kuvaavia rohkeita ja riskialttiita päätöksiä.

Kaikkiaan Paimion sähköiseen historiaan liittyy runsaasti luovaa työtä, innovatiivista rohkeutta ja sattumaa. LSS Oy:n jatkon kehitykselle olikin olennaista, että sen tukena toimi paikallinen asennus- ja urakointifirma. Paimiolaisen työläiskodin poika livari Lähteenmäki tarttui ennakkoluulottomasti tarjottuun mahdollisuuteen ja hankki itselleen todellisen tulevaisuuden amma- 
tin. "Sähköistysraivon" luoma markkinarako mahdollistikin menestystarinan, joka on Paimiossa vailla vertaa. Yhden miehen yrityksenä syntynyt pieni liike kasvoi varhaisten monttöörien ja tolppakenkäveljien kautta valtakunnantason teollisuusyritykseksi. Sen erikoisalaa olivat 1960-luvulle tultaessa oma teollisuustuotanto ja vaativat suursähköistysurakat. Lisäksi Iivari Lähteenmäen luomalla asennusliikkeellä oli merkittävä asema paikallisena työllistäjänä ja paikkakunnan sähköisen imagon keulakuvana.

Seuraavan kaavion (kaavio 1) lähtökohtana ovat sekä edellä esittämäni luvut LSS Oy:stä ja SLM:stä että näkemykseni Paimion paikallisen kehityksen (mikrotaso) taustalla vaikuttavista laajemmista makrotason syistä. Kaavio selittää sähköisen Paimion syntyyn vaikuttaneita taustatekijöitä. Siinä sähkö saa luonteen sekä teknisenä edistyksenä että kokonaisvaltaisena mikro- ja makrotason muutoksen heijastajana. Muutoksen reunaehdoiksi olen asettanut ekologiset, tekniset, taloudelliset ja henkiset reunaehdot.

\section{Kaavio 1}

Sähköisen Paimion kokonaisuus

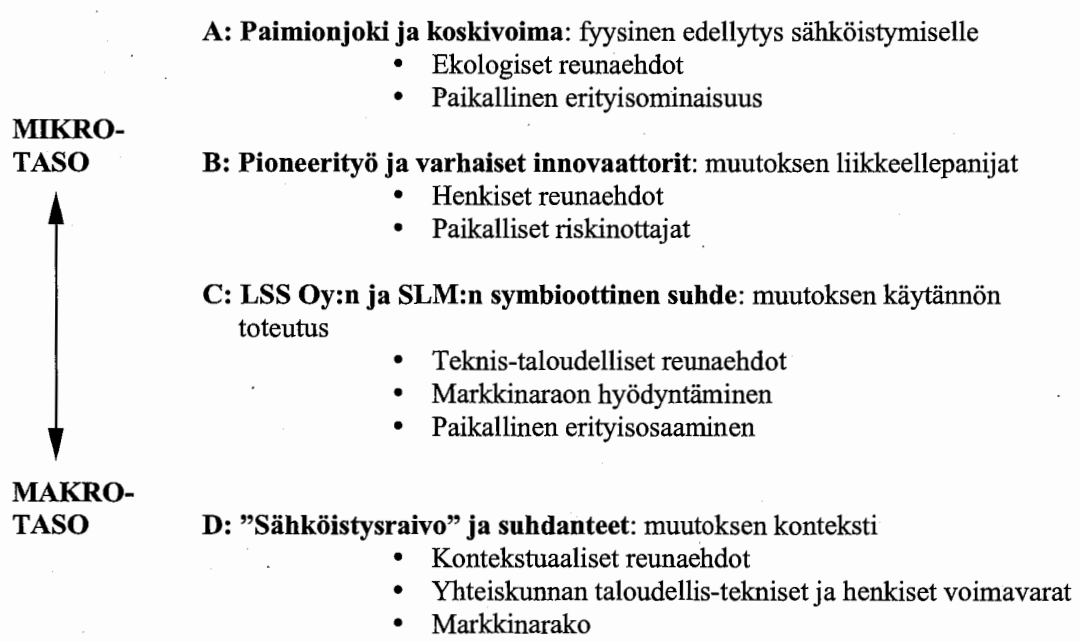

Lopuksi sijoitan sähköisen Paimion eli LSS Oy:n ja SLM:n kehitysjaksot osaksi sähköisen Suomen makrotason mallia. Kaaviossa 2 liitän Paimion kehityksen vaiheet osaksi sähköisen Suomen kehitysjaksoja kuvaavaa S-käyrää. Kaaviossa 3 esitän saman jaottelun selvyyden vuoksi myös taulukon muodossa. Näin tulkiten "sähköinen Paimio" jäsentyy elimelliseksi osaksi "sähköisen Suomen" kehitystä. Samalla mikro- ja makrotason kehityskaaret saavat niille kuuluvan dialektisen luonteen. 
Kaavio 2

Paimion kehityskaarì suhteessa Suomen sähköistymisen jaksoihin
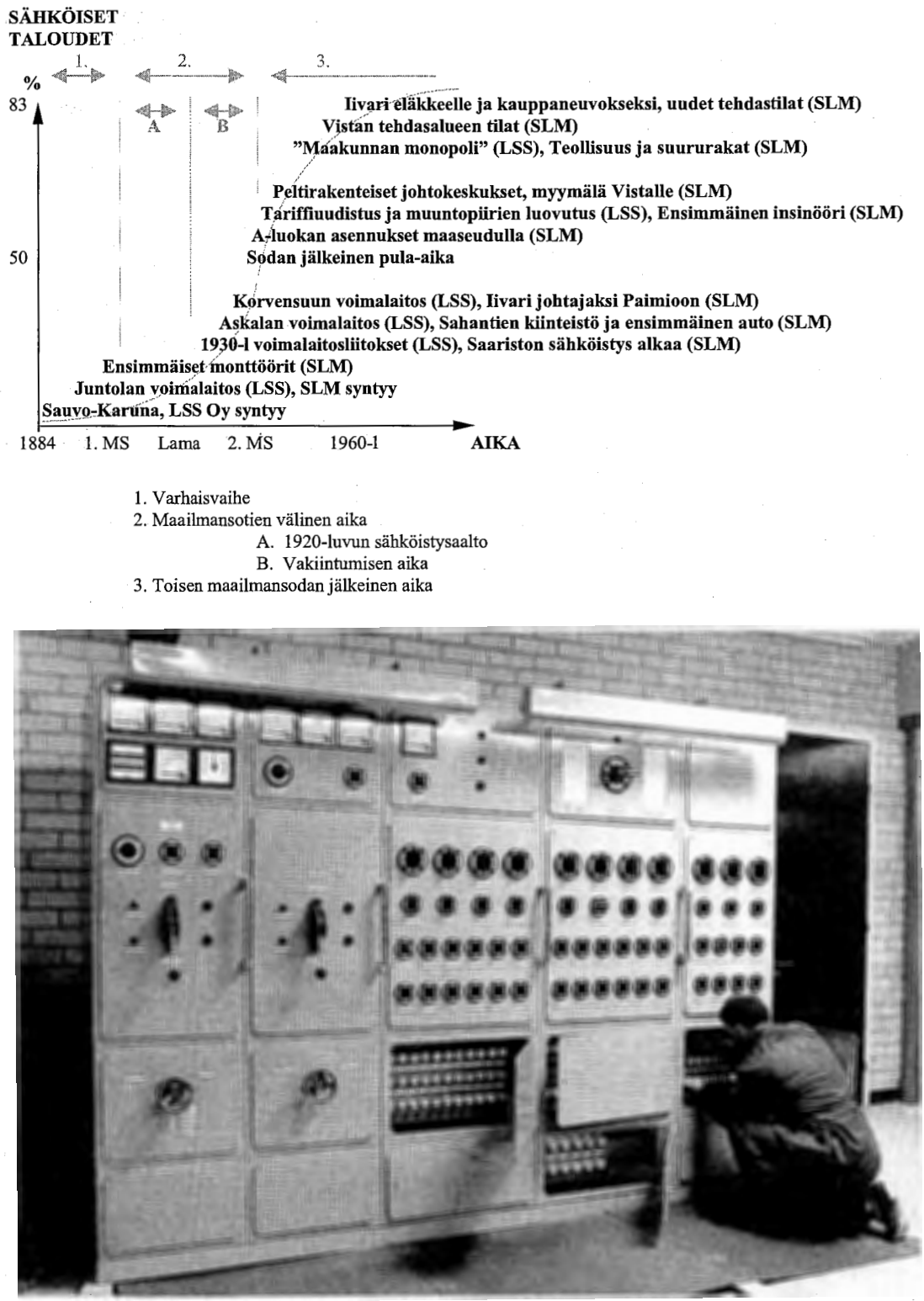

SLM siirtyi 1960-luvulle tultaessa suurteollisuuden ja Turun yliopiston kaltaisiin vaativiin sähköistysurakoihin. Kuvassa viimeistellään vartioalus "Silmään" rakennettua 2 x 95 kVA:n laivapäätaulua. Kuva: Paimion Sähkömuseo 
Kaavio 3

Sähköisen Paimion vaiheet

\section{KEHITYSJAKSOT}

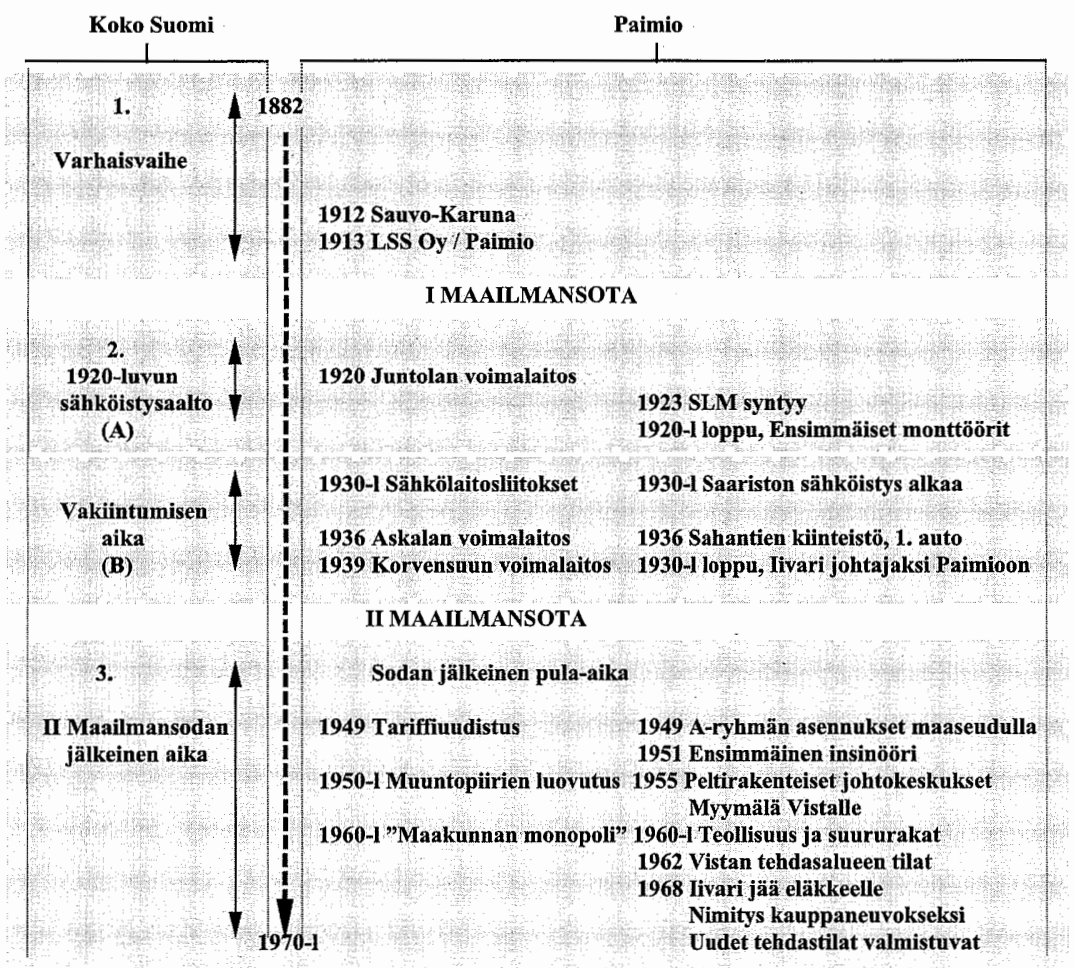

\section{LÄHTEET}

\section{Arkistolähteet}

TURUN YLIOPISTO, KULTTUURIENTUTKIMUKSEN LAITOS, KANSATIEDE (TYKL)

Fingerroos, Outi 1998. Valon aika Paimiossa. Sähkö mikro- ja makrotason yhteisöllisyyden ja elämäntavan kentässä ennen 1960-luvun loppua. Litteraatiot, nro 4.

TURUN YLIOPISTO/ USKONTOTIETEEN JA FOLKLORISTIIKAN ÄÄNITEARKISTO (TKU). Sähkö ja sähkömiesperinne, haastattelut. Pertti Itkonen 1990.

TKU/A/90/36-37: Karp, Martti. Synt. 1921, Viipuri.

TKU/A/90/40: Rantanen, Martti. Synt. 1918, Paimio.

PAIMION SÄHKÖMUSEO

Sähkö, Paimio ja sähkömiesperinne, haastattelut (SMH). Johanna Lehto-Vahtera 1996.

JL: Jukka Lähteenmäki. Synt. 1929, Paimio.

MR: Martti Rantanen. Synt. 1918, Paimio.

PS: Paavo Sahlström. Synt. 1913, Perniö.

Sähkö, Paimio ja sähkömiesperinne, valokuvat. Sähkömuseon arkistokokoelma. 
Kirjallisuus:

ABB LINKKI 1993: Tyvestä tolppaan. SLM 70-vuotta. ABB-Linkki 53 (4): 12-13.

Ahvenainen, Jorma \& KuUsterä, Antri 1982: Teollisuus ja rakennustoiminta. Ahvenainen, JorMA \& PihKala, ERKKI \& Rasila, Viljo (toim.): Suomen taloushistoria 2. Teollistuva Suomi, s. 222-261. Helsinki: Kustannusosakeyhtiö Tammi.

Ahvenainen, Jorma \& Vartiainen, Henri J. 1982: Itsenäisen Suomen talouspolitiikka. AhvenaINEn, Jorma \& PihKala, ErkKi \& RaSila, Viljo (toim.): Suomen taloushistoria 2. Teollistuva Suomi, s. 175-261. Helsinki: Kustannusosakeyhtiö Tammi.

ALAPURO, RisTo 1985: Yhteiskuntaluokat ja sosiaaliset kerrostumat 1870-luvulta toiseen maailmansotaan. VALKONEN, RISTO \& kump. (toim.): Suomalaiset. Yhteiskunnan rakenne teollistumisen aikana, s. 36-100. Porvoo: WSOY.

ANTtாA, VeIKKo 1976: Alueelliseen pienyhteisöön kohdistuvasta tutkimuksesta. Alueelliset pienyhteisöt tutkimuskohteina. Symposium Jyväskylässä 16.-17.9.1976: 3-16. Moniste. Jyväskylä: Jyväskylän yliopiston etnologian laitos.

AsP, ERKki 1969: Sosiaalinen muutos 1. Monisteita 20. Turku: Turun yliopiston sosiologian laitos.

BJörkLund, ANDERs 1986: Den omvälvande elektriciteten. Dragos, GEorg \& STIBY, GILdA: När elektriciteten kom. Om landbygdens elektrifiering med exempel från Edsbyn $i$ Hälsingland, s. 9-18. Stockholm: Carsons, Sveriges Tekniska Museum.

COVAN, Ruth SchWARTz 1983: More Work for Mother. The Ironies of Household Technology from The Open Heart to The Michrowave. New York: BasicBooks.

Dragos, Georg \& StiBy, GiLda 1986: När elektriciteten kom. Om landbygdens elektrifiering med exempel från Edsbyn i Hälsingland. Stockholm: Carsons, Sveriges Tekniska Museum.

EMÄNTÄLEHTI 1922: Kotitalousopettajat ja keittiön koneellistaminen. Emäntälehti. Martta-yhdistyksen äänenkannattaja: 20 (2): 34-35.

ERIKSSON, JAN-THURE 1993: Yleinen sähkötekniikka ja sähkökoneet. KESKINEN, RISTo (toim.): Suomen energiatekniikan historia. Teknis-historiallinen tutkimus energian tuottamisesta ja käytöstä Suomessa 1840-1980. Osa 2, s. 57-98. Tampereen teknillisen korkeakoulun julkaisuja 115. Tampere: Tampereen teknillinen korkeakoulu.

GARNERT, JAN 1993: Anden i lampan. Etnologisk perspektiv på ljus och mörker. Stockholm: Carsons.

GRANBERG, LEO 1992: Vaikea rooli - pienviljelijän tie asutustoiminnan ajalta tietoyhteiskuntaan. RAHIKAINEN, MARJATTA (toim.): Suuri muutos. Suomalaisen yhteiskunnan kehityspiirteitä, s. 52-67. Helsinki: Helsingin yliopisto, Lahden tutkimus- ja koulutuskeskus.

HaApala, PertTi 1995: Kun yhteiskunta hajosi. Suomi 1914-1920. Kleio ja nykypäivä. Helsinki: Painatuskeskus.

HaAtaja, Lauri 1987: Jälleen rakentava Suomi. Zetterberg, Seppo (toim.): Suomen historian pikkujättiläinen, s. 737-845. Porvoo: WSOY

HaAvisto, Heikxi 1982: Sähkön tuotanto. Simola, Osmo (toim.): Vuosisata sähköä Suomessa, s. 37-53. Helsinki: Suomen Sähkölaitosyhdistys.

HAIKALA, Sisko 1987: Lounais-Suomen Sähkö-Osakeyhtiö 1912-1987. Paimio: LSS Oy.

HERRANEN, TıMo 1996: Valtakunnan sähköistyskysymys. Strategiat, siirtojärjestelmät sekä alueellinen sähköistys vuoteen 1940. Bibliotheca Historica 14. Helsinki: SHS.

Hietala, Marjatta 1987: Services and Urbanization at the Turn of the Century. The Diffusion of Innovations. Studia Historica 23. Helsinki: SHS

1991: Myytti perifeerisestä Suomesta. Kleio. Historian päivät 1991: 5-15.

HoNkala, Nillo 1966: Suomen sähkölaitosyhdistys 1926-1966. Helsinki: Suomen sähkölaitosyhdistys.

Hughes, ThOmas P. 1983: Networks of Power. Elektrification of Western Society 1880-1930. Baltimore: John Hopkings University Press.

InNAmAa, KertTu 1973: Isovihan ajasta 1960-luvulle. ErkKola, Toini \& von Hertzen, Erik \& InNamaA, Kerttu: Paimion historia, s. 351-887. Paimio: Paimion kunta, Paimion seurakunta.

Itkonen, Pertti 1989: Paimion sähkömuseon perussuunnitelma. Paimio: LSS Oy, Paimion kunta, SLM.

JAAKKOLA, ArTo 1982: Sähkölaitostoiminnan alkuvaiheet Suomessa. Simola, Osmo (toim.): Vuosisata sähköä Suomessa, s. 17-29. Helsinki: Suomen Sähkölaitosyhdistys r.y. 
ennen 1960-lukua

KALPA, HARri 1973: Tyvestä tolppaan. SähköLähteenmäki 50-vuotta. Paimio: SLM.

KERN, STEPHEN 1994: The Culture of Time and Space 1880-1918. Seventh Printing. Cambridge: Harvard University Press.

KorHONEN, TePpo 1985a: Valon juhla. Kotiseutu 76 (2): 76-80.

KorHonen, TEPPO 1985b: Festival of Light. Ethnos-toimite 6: 101-116.

Lehtonen, JuHan U. E. 1984: Kaupungistuva kansankulttuuri. TommIla, Päıviö \& Reitala, Aimo \& Kallio, VeIKKo (toim.): Suomen kulttuurihistoria III: itsenäisyyden aika, s. 593626. Porvoo: WSOY.

KäRNÄ, JUHANI 1993: Valaistus. Keskinen, RIsTo (toim.): Suomen energiatekniikan historia. Teknis-historiallinen tutkimus energian tuottamisesta ja käytöstä Suomessa 1840-1980. Osa 2, s. 147-163. Tampereen teknillisen korkeakoulun julkaisuja 115. Tampere: Tampereen teknillinen korkeakoulu.

MCLuHAN, MARSHALl 1965: Understanding Media: The Extension of Man. New York: McGrawHill Book Company. (1964)

MICHELSEN, KARL-ERIK 1987: Teknologia ja sen historian tutkiminen. Historiallinen aikakauskirja 85 (3): 187-202.

Myllyntaus, Timo 1991: Electrifying Finland. The Transfer of a New Technology into a Late Industrialising Economy. Helsinki: ETLA.

Ollila, ANNe 1993: Suomen kotien päivä valkenee. Marttajärjestö suomalaisessa yhteiskunnassa vuoteen 1939. Helsinki: SHS.

Pihkala, Erkki 1982: Teollisuus Suomi 1945-1980. Ahvenannen, Jorma \& Pihkala, Erkki \& Rasila, VILJo (toim.): Suomen taloushistoria 2. Teollistuva Suomi, s. 370-386. Helsinki: Kustannusosakeyhtiö Tammi.

PylkKänen, Matti 1982: Maaseudun sähköistäminen. Simola, Osmo (toim.): Vuosisata sähköä Suomessa, s. 30-36. Helsinki: Suomen Sähkölaitosyhdistys.

RANTALA, JuSSI 1993: Tolppakenkäveljet toivat valon pimeyteen. Turun Sanomat Extra, 16.3.1993: 8.

RINNE, Torvo T. 1962: Lounais-Suomen Sähkö-Osakeyhtiö 1912-1962. Paimio: LSS Oy.

Roos, J. P. 1987: Suomalainen elämä. Tutkimus tavallisten suomalaisten elämänkerroista. Helsinki: SKS.

Ruotsala, Helena 1992: Oulujoen rakentamisen ja säännöstelyn sosiokulttuuriset vaikutukset. Tutkimusraportteja 2. Turku: Turun yliopisto, Kansatiede.

RÄSÄNEN, MATTI 1978: Korkeasuhdanne ja talonpoikainen rahankäyttö. Kotiseutu 69 (4-5): 121128.

SALOKangas, Raimo 1987: Itsenäinen tasavalta. ZeTterberg, SePpo (toim.): Suomen historian pikkujättiläinen, s. 603-703. Porvoo: WSOY.

Santala, VäINö 1962: Näin Paimion kehittyvän. KaJAnoja, PekKa (toim.): Paimio-Seuran vuosikirja 2: 41-47.

SARPARANTA, A. A. 1938: Maaseudun sähköistys. Teknillinen aikakauslehti 28(10): 366-275.

SIMOLA, TAPIO 1993: Julkinen kulutus ja palvelut. KESKINEN, RISTO (toim.): Suomen energiatekniikan historia. Teknis-historiallinen tutkimus energian tuottamisesta ja käytöstä Suomessa 1840-1980. Osa 2, s. 315-328. Tampereen teknillisen korkeakoulun julkaisuja 115. Tampere: Tampereen teknillinen korkeakoulu.

Soininen, Arvo M. 1982: Maa- ja metsätalous. Ahvenainen, Jorma \& Pihkala, ErkKi \& Rasila, VILJo (toim.): Suomen taloushistoria 2. Teollistuva Suomi; s. 27-51. Helsinki: Kustannusosakeyhtiö Tammi.

STÖPSELI 1983: 60 sähköistä vuotta. Stöpseli (4): 3-18.

TuRun SANOMAT 1962: Lounais-Suomen Sähkö Oy toiminut 50-vuotta. Turun Sanomat 89 (166):8.

UITTOMÄKI, KARI 1997a: Lounais-Suomen Sähkö-Oy:n ja SähköLähteenmäki Oy:n vaikutus Paimion kunnan kehitykseen. Suomen historian proseminaariesitelmä. Turku: Turun yliopisto, Suomen historia.

1997b: Suomen sähköisin kunta - onnea ja tietoista työtä. Kunnallislehti 81 (52): 10.

UUSI PÄIVÄ 1960: Huimia kilowattihintoja maaseudun sähköyhtiöillä. "Sähköpolitiikka" epäedullista pienkuluttajalle. Uusi Päivä 15 (299): 1-2.

Vihavainen, Timo 1987: Hyvinvointisuomi. Zetterberg, Seppo (toim.): Suomen historian pikkujättiläinen, s. 879-915. Porvoo: WSOY.

VIRrankoski, Pentti 1986: Talonpoikaiskulttuuri. TommILa, PäIviö \& Reitala, Aimo \& Kallo, VeIkкo (toim.): Suomen kulttuurihistoria III, s. 544-559. Porvoo: WSOY.

WIEgelmann, GüNTER 1977: Theorien und Methoden. WIEgelmann, GüNTER \& ZeNDER, MatThIAS \& HeLfurth, Gerhard (toim.): Volkskunde, s. 39-96. Berlin: Erich Schmidt Verlag. 
OUTI FINGERROOS: Electricity and the age of light - a view of the change to
modernity in the countryside before the 1960's

I shall study electricity from the viewpoint of "the age of light". I see electricity as a predominating process at both the macro- and micro-levels, through which electrification at the national level, government policy and prevailing economic circumstances influence the structural levels below and vice versa. My interpretation is that electricity is a technological advancement and totality consisting of both an array of technical motifs and scientific laws, as well as economic resources, political authority and social relationships.

The history of nation-wide electrification has included much creative work and will. The early pioneers learned from abroad and made courageous decisions, although prone to risk, in the domain of electrification. The Finnish quest for knowledge was multifarious; models were sought from various sources and given practical application. At the same time electricity was a category representative of the creative mind. At the practical level the vision was given the clothing of a multitude of advertising slogans, which even showed the form of the changes that lighting could be expected to bring. Both a conscious and unconscious attempt at the reform of the smaller communal unit and later the way of life of the whole of society remained concealed in the background.

"The age of light" meant a permanent change in the way of life at the micro-level, because it brought with it a new way of arranging time, places and the collectivity. Electrification at the micro-level was influenced by a desire to join together the crowd of users of electricity, and by the need to rationalise labour intensive agriculture. The lighting and electricity propaganda coming down from above did not, nevertheless, suddenly make the life of the peasant modern, clean and hygienic. The countryside was a serious economic vacuum, and smallholders did not have the means to procure modern innovations. Because of the high cost of investment in electric energy even the wealthier homes were at first only lit up - rather than being efficient technical showcases wherein the mother was given a new supervisory role. Indeed, the lack of investment in electrification forced people to stick to traditional methods of farming.

With regard to electrification Paimio is an unusual municipality, since two nation-wide large scale electric energy enterprises are situated there: SähköLähteenmäki (now ABB) and LounaisSuomen Sähkö-Osakeyhtiö (now Länsivoima). Those companies that have benefited from the market openings brought through the structural changes occurring in Finnish society in the 1900's have become established as a result of the courageous decisions of local innovators and have grown to become top-ranking units in the context of the "electrification fury". Power from the waterfall currents of the River Paimio has been the condition for this success. The history of the electrification of Paimio, which carries the image of the most electrified municipality in Finland, is a blend of local ecology, innovativeness of the early pioneers, symbiotic cooperation between the electricity producing Lounais-Suomen Sähkö-Osakeyhtiö and the contractor SähköLähteenmäki, and also of the general state of the Finnish economy. 